\title{
Complex geoarcheological investigation at the Székelyudvarhely-Kadicsfalva/Cãdiseni site (Romania)
}

\author{
Katalin Náfrádi*, Gergő Persaits \\ Department of Geology and Paleontology, \\ University of Szeged, Szeged
}

\author{
Pál Sümegi \\ Department of Geology and Paleontology \\ University of Szeged, Szeged \\ Institute of Archaeology, \\ Hungarian Academy of Sciences
}

Environmental historical analyses, including sedimentological, pedological, palynological, archeobotanical and phytolith analyses were carried out on samples derived from the Kadicsfalva/Cãdiseni archeological site. Our aim was to provide paleoenvironmental data to the archeological results in order to reconstruct the former milieu of the Gothic population, and to provide information regarding their environment management. At the end of the Pleistocene loess and alluvial loess developed from the eolian dust that accumulated on the wet surfaces of the Pleistocene sediments. The site provided favorable conditions to host a settlement and supports its long-term colonization owning to the riverside terrace surface location. The comparative analysis of the recent and the Gothic soil horizon proved that the recent soil horizon is over-utilized; its productivity can be maintained only by intensive fertilization and almost every one of its parameters is below the element and nutrient composition of the Gothic soil horizon.

Key words: archeological site, sedimentological analysis, pollen analysis, phytolith analysis, environmental history, Gothic settlement

\section{Introduction}

A complex environmental and geoarcheological reconstruction (Sümegi 2003) was carried out on samples derived from the archeological site of Kadicsfalva/Cãdiseni, focusing on the excavated Gothic (Sântana de Mures/ Marosszentanna culture) settlement, spatially and temporally. The Gothic burial site of Sântana de Muresis of crucial significance in the archeology of the period

\footnotetext{
Addresses: K. Náfrádi, G. Persaits, P. Sümegi: H-6722 Szeged, Egyetem utca 2-6, Hungary P. Sümegi: H-1014 Budapest, Úri u. 49, Hungary, corresponding author e-mail: nafradikata@gmail.com

Received: March 12, 2013; accepted: June 21, 2013
} 
of Great Migrations (Pósta 1906; Kovács 1912). It was the first burial ground to be discovered that was identified by a person who played an important role in lateRoman and early Medieval history, and the first to benefit from a fully professional assessment in archeological publications (Bóna 1986). Sântana de Mures was synonymous with the Gothic culture in the eyes of archeologists and historians who studied the Visigoths (Bóna 1986). The areas bearing archeological traces of the 'Tervingi Goths' settlement do not fully justify the appellation 'forest dwellers' - such as the Transylvanian plain (Câmpia Transilvaniei, Mezôség), Odorhei region (Scaunul Odorhei, Udvarhelyszék), the Burzenland (Tara Bârsei, Barcaság), the Covasna (Trei-Scaune, Háromszék), Wallachia, and the undulating plains in the valleys of the Siret (Szeret), Prut, and Dniester (Nistru, Dnyeszter) rivers. Over the century of Gothic rule, forests were widespread in the center of Gutthiuda, "Land of the Goths" (Wolfram 1990), and in fact the population settled around the forests. To the north and to the west, the forests provided the Goths with a protective barrier (Bóna 1986). Food remnants in graves confirm the Gothic Bible's reference (the author of which was Wulfila or Ulfila in 4th century AD; based on Bóna 1986; Kiss 2004) to the animals raised by the Visigoths: cattle, pigs, sheep, and goats, as well as horses and donkeys for draught. The commonly found traces of poultry bones (hens, roosters) and eggs in graves indicate the intensive character of this ancillary animal husbandry. Indeed, only a few traces of mammals were found in Transylvanian Gothic graves (Bóna 1986). It is unlikely that the Visigoths had large herds or flocks, for otherwise they would have left traces of settlement in the area of fine pastures on mountainsides and in the narrower valleys. Indeed, Wulfila's Bible alludes to an intensive form of animal husbandry. That is why we analyzed the central part of the Gothic-occupied region around Odorei Secuiesc (Székelyudvarhely), in order to reconstruct the basis of Gothic economy and the natural and transformed environment of the Gothic settlement.

To this end we applied the methods of Birks and Birks (1980) to reconstruct the former environment of the Gothic (Sântana de Mures culture) site. This included sampling sections and cutting cores at the archeological site for the geologic and paleontological analysis of the bedrock. We conducted sedimentological, pedological, malacological, macrobotanical and pollen analyses. By comparing the results we were able to reconstruct the past milieu of the Gothic populations and how they managed their environment. In order to attain greater complexity we applied phytolith analysis, which provided extra information regarding the paleovegetation and thus completes the results of our study. So with respect to the results, beside pollen analysis, locally accumulated plant microfossils complements our research.

Phytoliths are of particular interest to archeologists because i) they are highly resistant to decay and are capable of surviving in such places and under extreme conditions where preservation of other types of archeological plant remains, e.g. pollen, is not possible, ii) phytoliths are essentially stones; they are preserved 
indefinitely in all but the most extremely alkaline burial conditions (Piperno 1988) and iii) while pollen grains generally represent the vegetation of the study site usually at a greater regional scale, due to the general characteristics and easy transportation of the grains, phytoliths present very important information about the local vegetation or other events, since they are preserved where the plant material was actually deposited or carried onto. However, depositional conditions (by humans as in the case of wood used as fuel in kilns, animals or the original plant) must be clarified for accurate interpretation.

\section{Study area}

The study area Kadicsfalva/Cãdiseni (Fig. 1) is located in the northeastern suburb region of the town of Odorheiu Secuiesc, on the eastern side of the Transylvanian Basin, in the Székely Land (Terra Siculorum: Benkő 2012). The analyzed Gothic site can be found on the right side of Târnava Mare (NagyKüküllő) on a Pleistocene terrace, at the edge of the Odorheiu Secuiesc Basin. The basin, which was formed as a result of fluvial erosion, starts at the junction of Târnava Mare and the Brãdesti River (Fenyéd patak) and extends as far as Feliceni (Felsőboldogfalva) (Fodor 1936).

Pannonian sandstone and sand-clay-marl formations of the Transylvanian Basin constitute the near-surface part of the Odorheiu Secuiesc Basin. Thereafter volcanic formations were deposited; on the eroded surface of the volcanic material, fluvial deposits close the sedimentary sequence (Báldi 1980; Csontos 1995; Pécskay et al. 1995; Szakács and Krézsek 2007). The final part of the Quaternary fluvial deposit is the terrace sequence that was formed by the meandering fluvial system. On this surface, different cultures, including the

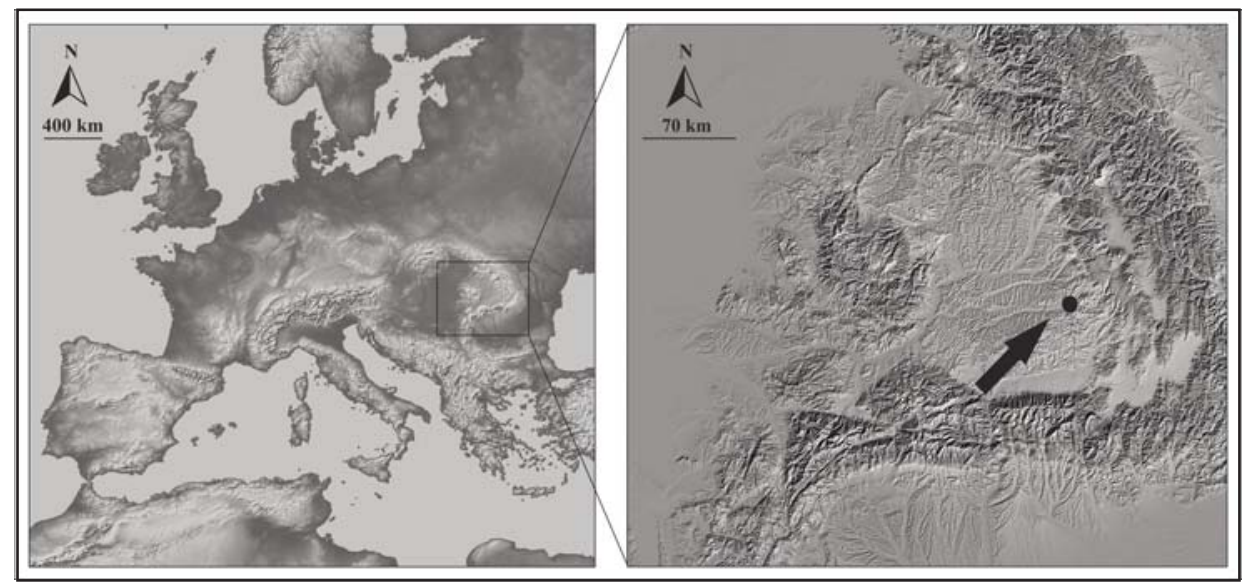

Fig. 1

Location of Kadicsfalva/Cãdiseni (black circle) (source: Timár et al. 2003; Unger and Timár 2005) 
Sântana de Mures-Chernyakhov culture, developed their settlements on the riverbank of Târnava Mare (Benkő 1992; Körösfői 2008; Körösfői et al. 2009, 2010).

The average altitude of the Odorheiu Secuiesc Basin is $470-480 \mathrm{~m}$ above sea level, so the climate of the basin is cold-continental. The mean annual temperature is $8.3^{\circ} \mathrm{C}$. The mean annual precipitation is $674 \mathrm{~mm}$. Due to the significant rainfall and the relatively low annual temperature the entire area was originally covered by forest belonging to the Carpathicum phytogeographic zone (Szász 1995). The characteristic arboreal association is Querco petreae-Carpinetum; along riverbanks it existed mixed with Fraxino-Ulmetum. One of the characteristics of the vegetation is that the elements of Symphyto cordati-Fagetum appear as well, since the highest point of the basin reaches the beech zone. On the other hand, from the head of Târnava River (Râul Târnava, Kükülló), species typical for beech forest can spread as hydrochores as well (Szász 1995; Gál 2004).

\section{Materials and methods}

\section{Field sampling}

Field sampling was carried out between the 24th and 28th of October 2010. We undertook several geologic drillings operations close to the archeological excavation of Kadicsfalva/Cãdiseni with a $5 \mathrm{~cm}$-diameter auger head drill, taking samples every $5 \mathrm{~cm}$. In addition a soil section was prepared at the archeological excavation site where the settling level and soil horizon of the Gothic culture could be studied. Sedimentological, pedological, archeobotanical and archeozoological analyses were performed on the core sediment in order to reconstruct the former environment of human populations. Sedimentological, geochemical, palynological, archeobotanical and malacological analyses were carried out on samples of archeological objects and samples of the soil section derived from the archeological site. The double flotation method according to the German standard (Jacomet and Kreuz 1999) was applied to the sediment samples. They were then sorted for archeozoological and archeobotanical analysis. For the computerized processing and the producing of layer diagrams the PSIMPOLL software (Bennett 1992) was used. In describing the colors of the sediment layers the Munsell Soil Color Charts were employed.

\section{Sedimentological and pedological analysis}

The granulometric analyses were carried out using the aerometer method (Casagrande 1934, 1947). This method appears to be inaccurate compared to various pipette (Kézdi 1970), laser and sedigraph measurement methods (Vendel 1959) but the comparison of the above-mentioned methods (Levant et al. 1987) indicates that the results of measurements employing methods of great accuracy (or, at least considered to be of great accuracy) should be compared only to each other, by employing the same method and measurement conditions. Otherwise, 
when comparing them to each other in a correlative way, they present a variety of results. By using the Casagrande measurement method (Casagrande 1934, 1947), the mechanical composition parameters can be measured and calculated quite quickly. Determination of weight percent organic matter and carbonate content in sediments by means of LOI (Loss On Ignition) was based on sequential heating of the samples in a muffle furnace (see Dean 1974; Bengtsson and Enell 1986; Veres 2002 for more details on the method). We also carried out calcimeter measurements and SOM quantity determination (Vendel 1959) for each section by control samples (Dean 1974; Bengtsson and Enell 1986; Veres 2002).

Sequential extraction methods have a long-established history in the analysis of geochemical composition. Some important results concerning many aspects of the methods used in this study (Dániel 2004) are presented in this section. After removal of macroscopic organic residues the samples were sieved to separate the $<2 \mathrm{~mm}$ fraction. The separated $<2 \mathrm{~mm}$ fraction was dried at $105^{\circ} \mathrm{C}$ for 2 hours. Three $1.0 \mathrm{~g}$ samples $/ 5 \mathrm{~cm}$ layer were separated for water extraction after drying. Distilled water was purified using a Millipore 5 Plus Water Purification System. A $100 \mathrm{ml}$ distilled and purified water was added to $1.0 \mathrm{~g}$ sample and was shaken for 1 hour. The water-soluble ion concentrations were recorded using the flame AAS technique in a Perkin-Elmer AAS-type 100 at the Department of Geology and Paleontology, University of Szeged, Hungary. Calibrations and measurements were performed in accordance with international standards following Pradyot (2002). Samples were measured 3 times to ensure reproducibility of the results, which is better than $0.1 \%$.

We presented the granulometric data, the carbonate content and mechanical composition statistics parameters using the PSIMPOLL software (Bennett 1992). These were presented by sections. The loose sediment categories and symbol system of Troels-Smith (1955) were employed to describe the deposit columns and series of layers. These categories are presented using section charts in describing the deposit layers.

\section{Pollen analysis}

Samples of $1 \mathrm{~cm}^{3}$ wet sediment were prepared for pollen analysis using standard acetyl methods (Moore and Webb 1978) and micro-sieving at $10 \mu \mathrm{m}$ (Bennett and Willis 2001). In order to determine the pollen concentration the Lycopodium spore tablet method was used (Stockmarr 1971). The pollen-rich organic material was mounted on a glass slide bonded in silicone oil. According to worldwide standards, for the pollen analysis at least 300 pollen grains of dryland plants are counted in order to achieve statistically significant results. Since in our samples the amount of Pinus sylvestris, which can be carried over a long distance, was very significant, we increased the analyzed pollen number per sample to 1000 in order to find taxa that occur less often or that produce less pollen grains. Nikon and Olympus polarization optical microscopes were used 
for the pollen identifications with magnifications from $\times 600$ to $\times 1000$. Identification of pollen and spores was undertaken using reference books (Moore et al. 1991; Reille 1992; Beug 2004) and pollen reference material of the University of Szeged, Department of Geology and Paleontology and the Paleontology Library of the Geological Institute of Hungary.

Calculations, numerical analyses and drawing of pollen diagrams were performed using the Psimpoll 4.26 software (Bennett 2005). Local pollen assemblage zones (LPAZs) were defined using optimal splitting of information content (Birks and Gordon 1985), zonation being performed using the 20 terrestrial pollen taxa that reached at least $5 \%$ in at least one sample.

\section{Archeobotanical analysis}

The archeobotanical material was obtained from samples from the archeological sections of objects from uniformly $2.7 \mathrm{~kg}$ of samples (Sümegi et al. 2011) according to the German standards (Jacomet and Kreuz 1999). We used the dual flotation method according to Gyulai (2001) using 0.5 and $0.25 \mathrm{~mm} \varnothing$ sieves. The archeobotanical material was predominantly charcoal. After drying, charcoal fragments were selected and counted. The three-directional sections of charcoal were analyzed using a Zeiss Jenapol polarization optical microscope with magnifications of $\times 100, \times 200$, and $\times 500$. Identification was carried out using the reference books of Greguss $(1945,1972)$ and Schweingruber $(1990)$.

\section{Malacological analysis}

The Quaternary malacological material was sampled at every $10 \mathrm{~cm}$, approximately from $100 \mathrm{~cm}^{3}$ of sediment, and from uniformly $2.7 \mathrm{~kg}$ of samples from archeological objects and features. During the sampling process and sample preparation we followed the guidelines of Krolopp (1983). We used $0.5 \mathrm{~mm} \varnothing$ sieves for the flotation method. Identification of the malacological fauna was carried out using the reference books of Kerney et al. (1983), Liharev and Rammelmeier (1962), Ložek (1964) and Soós (1943). We used the paleoecological studies of Ant (1963), Boycott (1934), Evans (1972), Ložek (1964), Meijer (1985) and Sparks (1961) to create paleoecological categories, as well as the distribution data and maps of Bába (1983a,b; 1986), Ehrmann (1933), Kerney et al. (1983), Klemm (1974), Liharev and Rammelmeier (1962), Ložek (1964) and Soós (1943).

\section{Phytolith analysis}

Samples for phytolith analysis are derived from the section of the 3rd sampling point and from the core cut next to the section, taken at $10 \mathrm{~cm}$ intervals. Five samples were taken from the culture horizon (GF-2 - GF-6) and 5 samples from the levels of the section and core that could be separated macroscopically (GF-1, GF-7 - GF-10). 
For the extraction we used our own system (Persaits 2010) that is based on the method of Piperno (2006) and Madella et al. (1998). Five $g$ of the subsamples were shaken in a 5\% Calgon solution for 6 hours. The organic content was destroyed with a 30\% hydrogen peroxide solution. After this the carbonate content was removed by $10 \%$ hydrochloric acid. The fraction larger than $250 \mu \mathrm{m}$ was separated by wet flotation; the clay content was separated using an Atterberg sedimentation cylinder. Thereafter the sample underwent flotation in a heavy liquid (density $=$ $2.3 \mathrm{~g} / \mathrm{cm}^{3}$ ). The phytoliths obtained by this method were collected with a Pasteur pipette, then washed in ethanol. Thereafter they were stored in glycerin. The extracted phytolith samples were mounted on slides in glycerin. For the identification process a Nikon optical microscope was used with $\times 500$ magnification. For the statistical analysis 200 phytoliths were counted in each sample. Classification of phytolith types was based on the Twiss et al. (1969) classification and Golyeva's (2001) interpretation of phytolith characteristics, using our own phytolith photographic and descriptive references.

\section{Statistical analysis}

The comparative analysis of the samples was carried out using the Bray-Curtis method (Southwood 1978). To determine the relationships, the procedure of Ward (1963) and Orlóci (1967) was used, following Podani (1978, 1979). Both the comparison analysis and the clustering were carried out by the help of the NUCOSA software package developed by Tóthmérész (1993). The groups distinguished on the dendrogram were considered to be the part of the same sedimentological, palynological or macrobotanical zones. The sedimentological, geochemical and palynological compounds of the samples originating from the sedimentary basin were evaluated by multivariate statistical analysis in order to bring forth the specifics of each environmental historical zone. The examination was carried out by principal component analysis (PCA) (standardized, mixed/ Rohlf/bi-plot), using the SYN-TAX 5.0 program of Podani (1993). The examinations consisted of sedimentological analysis, interpretation of organic remains and carbonate content analysis, describing the deposit layers, and of analyses of macrobotanical material and pollen grains. The results of the examinations conducted on the same samples were evaluated together, leading to a thorough understanding of the historical environmental changes in the study area.

\section{Results and discussion}

\section{Sedimentological analysis}

On the basis of the macroscopic characters of samples derived from the section of the 3rd sampling point and the core next to it (No. 6), the following genetic and sedimentological units could be distinguished, from bedrock to surface (Table 1 and Fig. 2). 
Table 1

Geologic section of the archeological site on the basis of the 3rd sampling point and 6th core

\begin{tabular}{|c|c|c|c|c|}
\hline $\begin{array}{l}\text { Depth } \\
\text { (cm) }\end{array}$ & Colour (Munsell) & Grain composition & $\begin{array}{c}\text { Genetical } \\
\text { appellation }\end{array}$ & $\begin{array}{c}\text { Character of } \\
\text { sediment }\end{array}$ \\
\hline $0-30$ & $\begin{array}{l}\text { Yellowish brown } \\
\quad(10 \text { YR 5/8) }\end{array}$ & Silty clay & $\begin{array}{l}\text { Recent cultivated } \\
\text { soil horizon }\end{array}$ & $\begin{array}{l}\text { Mixed due to human } \\
\text { impact and slope } \\
\text { processes }\end{array}$ \\
\hline $30-60$ & $\begin{array}{c}\text { Dark yellowish brown } \\
(10 Y R 4 / 6)\end{array}$ & Silty clay & Cambisol 2B & Turbated, with roots \\
\hline $60-90$ & $\begin{array}{c}\text { Dark grayish brown } \\
(10 \mathrm{YR} 4 / 2)\end{array}$ & Silty clay & $\begin{array}{c}\text { Cambisol transition } \\
\text { level }\end{array}$ & $\begin{array}{l}\text { Turbated, small } \\
\text { findings occur }\end{array}$ \\
\hline $90-140$ & $\begin{array}{l}\text { Very dark grey } \\
(10 \mathrm{YR} 3 / 1)\end{array}$ & Silty clay & Cambisol 1A & $\begin{array}{c}\text { Gothic level, } \\
\text { ceramics, bones and } \\
\text { charcoals }\end{array}$ \\
\hline $140-190$ & $\begin{array}{l}\text { Very dark brown } \\
(10 \mathrm{YR} 2 / 2)\end{array}$ & Silty clay & Cambisol $1 \mathrm{AB}$ & $\begin{array}{c}\text { Turbated, few } \\
\text { findings }\end{array}$ \\
\hline $190-230$ & $\begin{array}{c}\text { Black } \\
(10 \mathrm{YR} 2 / 1)\end{array}$ & Silty clay & Cambisol 1B & $\begin{array}{l}\text { Turbated, prehistoric } \\
\text { findings }\end{array}$ \\
\hline $230-240$ & $\begin{array}{l}\text { Very pale brown } \\
(10 \mathrm{YR} 7 / 4)\end{array}$ & Fine silty coarse silt & $\begin{array}{c}\text { Alluvial loess, } \\
\text { bedrock }\end{array}$ & Pleistocene level \\
\hline $240-270$ & $\begin{array}{l}\text { Light grey } \\
(10 \mathrm{YR} 7 / 2)\end{array}$ & $\begin{array}{l}\text { Fine sandy coarse } \\
\text { sand }\end{array}$ & Fluvial deposit & $\begin{array}{l}\text { Pleistocene deposit, } \\
\text { terrace position }\end{array}$ \\
\hline
\end{tabular}

The bedrock of the excavated geologic formation at the archeological site is Pleistocene fluvial sand deposit. On the basis of the development of the layer this coarse sediment was accumulated in a braided channel system under significant energy conditions. At the end of the Pleistocene the river channel shifted and this layer underwent uplift; as a consequence, active fluvial accumulation ceased here and a periodically parched flat area developed at the edge of the Târnava River valley. At the end of the Pleistocene a significant amount of eolian dust accumulated and under periglacial conditions it became loess; on wet surfaces (under cyclically high water level) it became alluvial loess. The presence of the loess layer indicates that the Târnava River incised into its own deposits at the end of the Pleistocene, so the gravel deposit came to a raised position and loess diagenesis took place on the gradually parched surface. Based on the development of the loess layer it is probable that the erosion of the Târnava River to the gravel deposit occurred due to neotectonic processes and not because of climatic change.

Thereafter Cambisol (IUSS Working Group WRB 2007) (Table 2, Fig. 3) with a significant clay content developed on the alluvial loess. This soil horizon can be characterized by high SOM content that develops only in a closed deciduous forest. Thus it is probable that at the beginning of the Holocene a closed forested environment evolved and the forest ecosystem transformed the original fine silty coarse silt layer that was calcareous and poor in organic material into an organic material-rich, calcareous-free, silty clay layer. After the development of the closed forested environment, the appearance of human populations (prehistoric and Gothic) led to forest destruction due to land cultivation. On the basis of the development of the forest soil, reforestation and the regeneration of the soil 


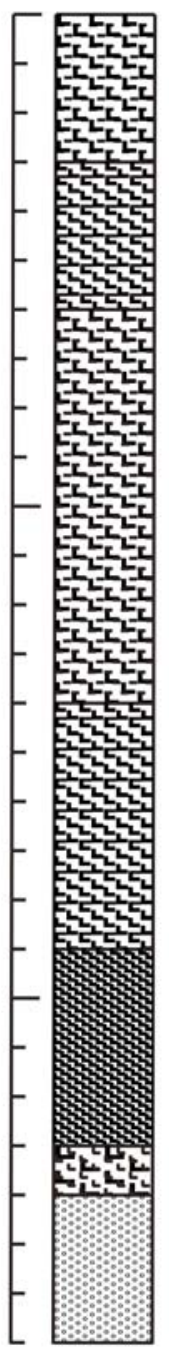

Yellowish brown silty clay (Sh2As2)

anthropogenic soil horizon (level A)

Dark yellowish brown silty clay (Sh1As3)

anthropogenic soil horizon (level B)
Fig. 2

Stratigraphy of the analyzed section at the 3rd sampling point

\author{
Very dark gray silty clay, \\ well-developed Cambisol \\ with clay illuviation \\ (Sh2As2) - Goth settling level
}

Very dark brown silty clay, well-developed Cambisol with clay illuviation

(Sh1As3)
Black silty clay, well-developed Cambisol with clay illuviation
(As4) - prehistoric settling level

Very pale brown fine silty coarse silt, alluvial loess (As1Ag3)

Pleistocene sediments of Târnava River between the pediment and the

Holocene alluvium, terrace location (Ga4)

occurred between these settlement periods. In this soil horizon (Table 2, between 160-170 cm) the clay content increased, while the ratio of coarse sediments decreased. In the horizon of human settlement the organic material increased and the carbonate content decreased (Table 2, Fig. 4, between 190-230 and 90-140 $\mathrm{cm})$, while the amount of coarse sediments increased and the clay content decreased. This indicates human impact and soil degradation (Willis et al. 1998).

Without human impact (i.e. roads, settlements and pasture lands) a closed forest would have developed in the area, and due to the significant amount of precipitation the development of Cambisol with clay illuviation would have continued. In addition, due to human impact and the open vegetation that 


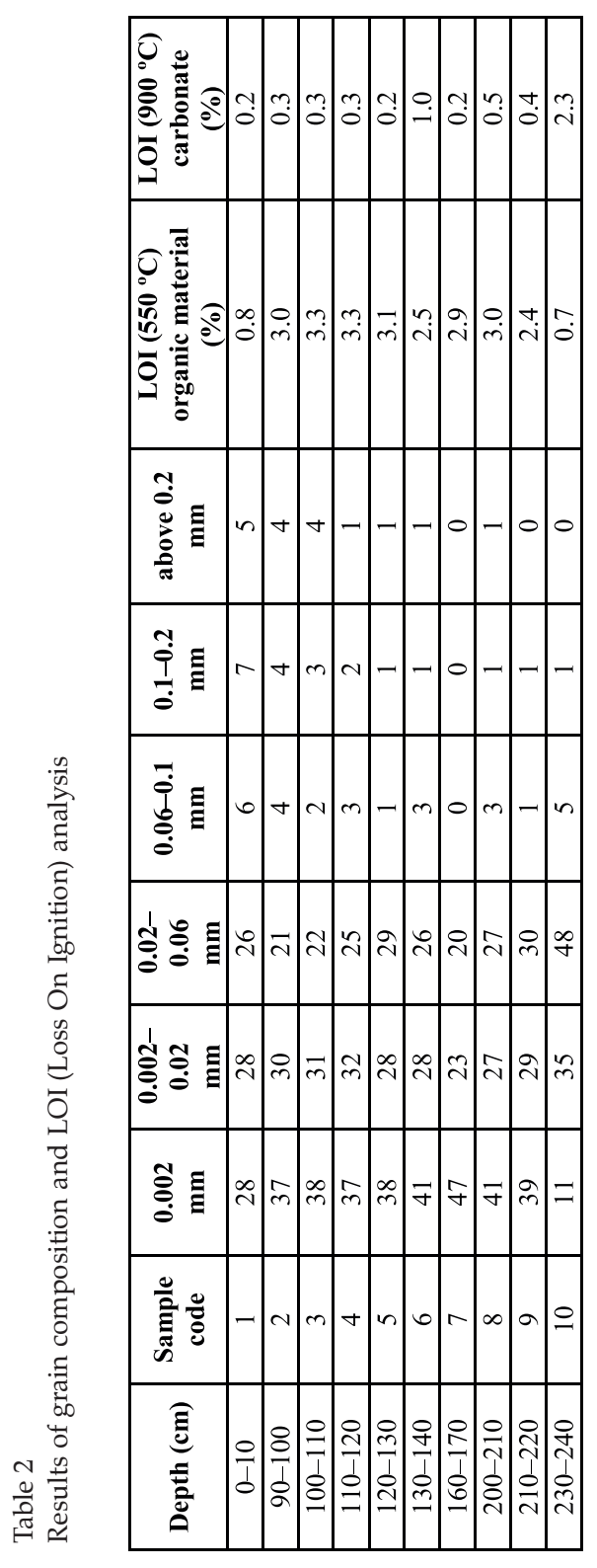

developed as a result of anthropogenic influences, the degradation of the Cambisol and the development of a secondary soil took place in the area. Toward the surface the color of the soil lightens and its organic material content decreases drastically, probably due to fluvial erosion (Alexander 1992; Zheng et al. 2005).

\section{Pedological analysis}

On the one hand, the results of pedological analysis support those of sedimentological analysis; on the other they enlarge them significantly. Measurements indicate neutral, slightly acidic $\mathrm{pH}$ throughout the section, especially in soil horizons. The highest carbonate and the lowest organic material and SOM content were found in the bedrock (alluvial loess); thus its $\mathrm{pH}$ was the highest (Table 3, between 6.96 and 7.93). The slightly acidic $\mathrm{pH}$ corresponds to the Cambisol, and the neutral $\mathrm{pH}$ to the loess formation environment.

The SOM and organic material content is very significant throughout the section, except for the bedrock. However, the effect of recent cultivation is observable, since the amount of organic material increased in the level of Gothic settlement (Table 3, between 90-140 cm) compared to the prehistoric and the Cambisol level (Fig. 4).

On the basis of the distribution of sodium, nitrogen, sulfur and zinc (Table

Fig. $3 \rightarrow$

Results of grain composition and LOI (Loss On Ignition) analysis 


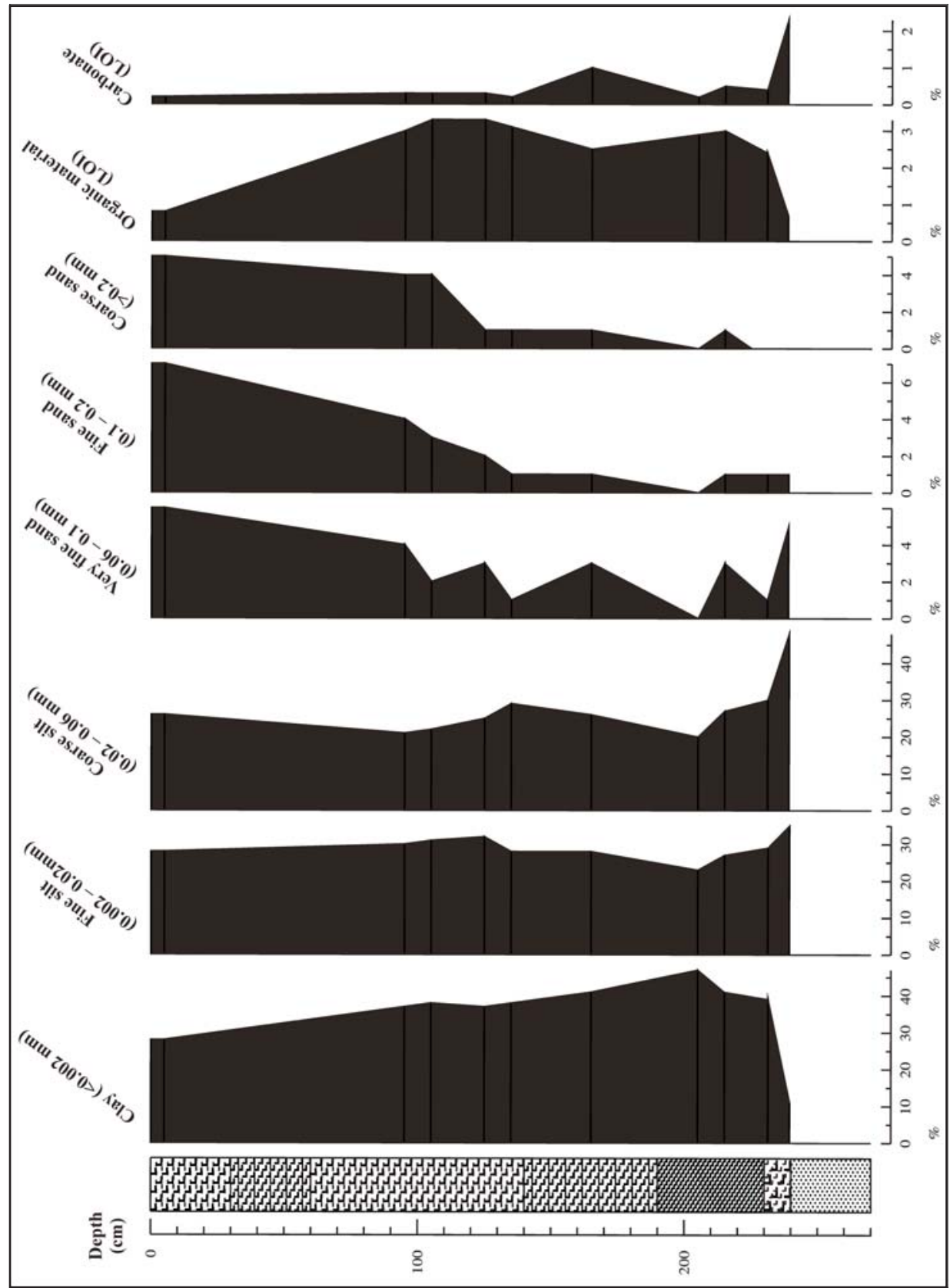


Table 3

Results of the pedological analysis of samples $1\left(\mathrm{~K}_{\mathrm{A}}=\right.$ Arany type plasticity index $)$

\begin{tabular}{|c|c|c|c|c|c|c|c|}
\hline Depth (cm) & $\begin{array}{c}\text { pH } \\
\left(\mathbf{H}_{2} \mathbf{O}\right)\end{array}$ & $\underset{(\mathbf{K C l})}{\mathbf{p H}}$ & $\mathbf{K}_{\mathbf{A}}$ & $\begin{array}{c}\text { Total salt } \\
\text { content } \\
(\mathbf{m} / \mathbf{m} \%)\end{array}$ & $\begin{array}{c}\mathrm{CaCO}_{3} \\
(\mathrm{~m} / \mathrm{m} \%)\end{array}$ & $\begin{array}{c}\text { SOM } \\
(\mathrm{m} / \mathbf{m} \%)\end{array}$ & $\begin{array}{c}\mathrm{SO}_{4}-\mathrm{S} \\
(\mathrm{mg} / \mathrm{kg})\end{array}$ \\
\hline $0-10$ & 7.73 & 6.71 & 41 & 0.03 & 0.19 & 0.68 & 3.41 \\
\hline $90-100$ & 7.60 & 6.53 & 46 & 0.04 & 0.28 & 2.93 & 5.49 \\
\hline $100-110$ & 7.47 & 6.49 & 48 & 0.04 & 0.28 & 3.21 & 4.11 \\
\hline $110-120$ & 7.51 & 6.44 & 50 & 0.03 & 0.28 & 3.11 & 4.11 \\
\hline $120-130$ & 7.52 & 6.57 & 48 & 0.03 & 0.19 & 2.97 & 3.65 \\
\hline $130-140$ & 7.53 & 6.76 & 48 & 0.08 & 0.94 & 2.32 & 11.0 \\
\hline $160-170$ & 7.63 & 6.62 & 44 & $<0.02$ & 0.19 & 2.30 & 5.03 \\
\hline $200-210$ & 7.53 & 6.76 & 44 & $<0.02$ & 0.47 & 2.93 & 5.03 \\
\hline $210-220$ & 7.57 & 6.70 & 45 & $<0.02$ & 0.38 & 2.32 & 5.95 \\
\hline $230-240$ & 7.93 & 6.96 & 38 & 0.04 & 2.19 & 0.61 & 6.41 \\
\hline
\end{tabular}

4) the original Holocene soil that developed on the alluvial loess was the most productive among the excavated soil horizons (Ciolkosz et al. 1989). The soil level between 160 and $170 \mathrm{~cm}$ also stood out, free of human impact and indicating strong reforestation between the settlement period of prehistoric populations and the migration period.

Compared to this, in the Gothic level the natural productivity of the soil (nitrogen content) decreased. However, the high SOM, organic material and phosphate content indicate that the Gothic population consciously increased the productivity of the deforested forest soil with manure (Ciolkosz et al. 1989). The phosphate content indicates not only the Gothic settlement but also the significant animal husbandry they carried out (Koopmans et al. 2001). The change of the zinc content indicates that the fertilization in the Gothic level is primarily associated with animal feces (Schlegel et al. 2008). The pedological analysis indicates that the structure and layers of the forest soil did not change during the prehistoric and the Gothic settlement period, but that the element content changed significantly. During the same time the content of magnesium did not change.

The appearance of copper can be related to industrial activity, but this element has links to organic material (Braun et al. 2005), so with the fluctuation of the organic material content its appearance and concentration changes in parallel with it. Thus, because of the change of the organic material content in our section, industrial activity is not the cause of the change of the copper content.

The manganese content is related to the former ground water level, cyclic desiccation and iron nodule formation (Nowlan 1976; Solti 2000). By the alteration of the manganese content we can reconstruct four significant periods (Table 4, depths between $230-240,160-170,120-130$ and 110-120) that are characterized by

Fig. $4 \rightarrow$

Results of the pedological analysis of samples 


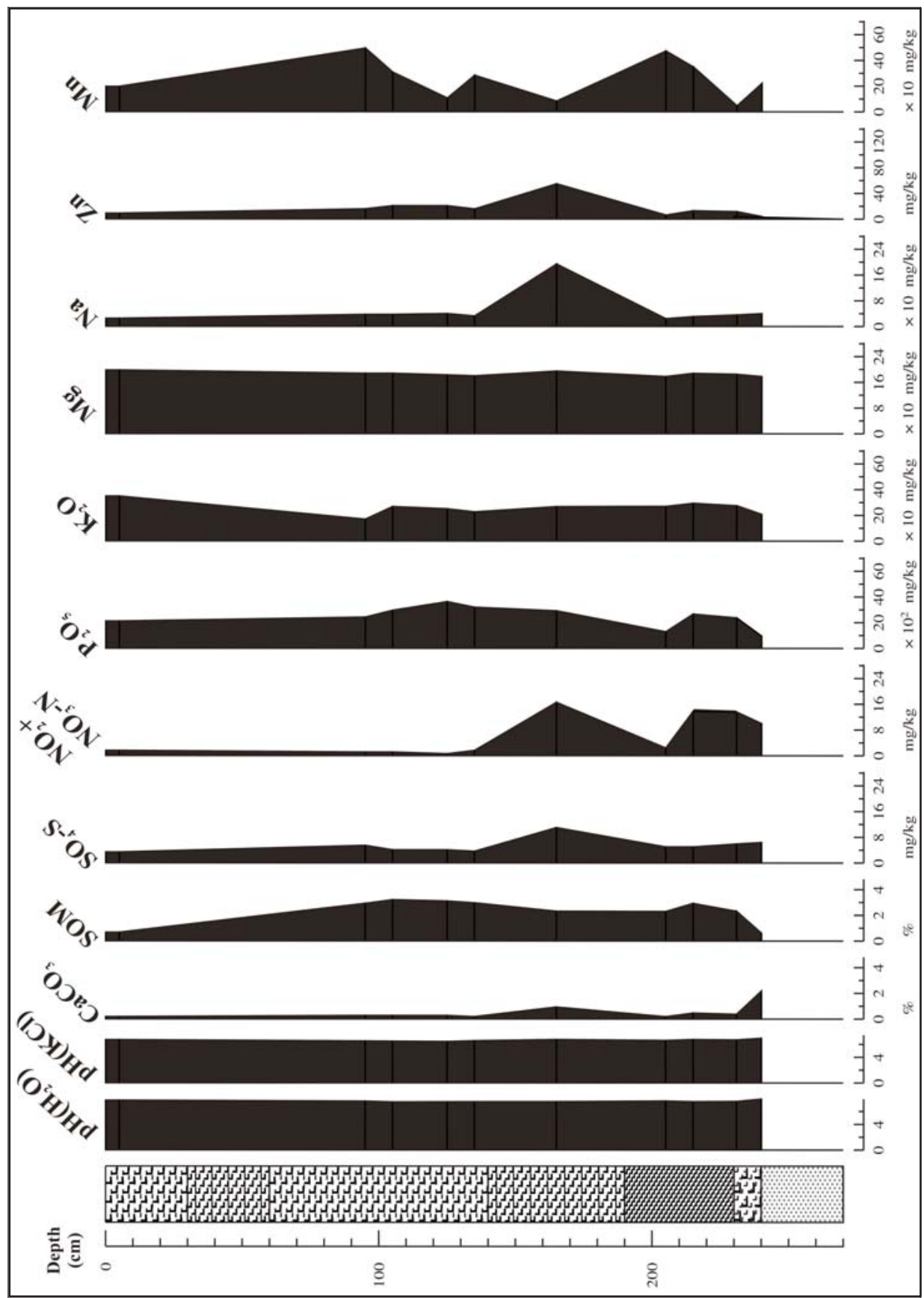

Central European Geology 55, 2012 
Table 4

Results of the pedological analysis of samples

\begin{tabular}{|c|c|c|c|c|c|c|c|c|}
\hline Depth (cm) & $\begin{array}{c}\mathrm{NO}_{2}+ \\
\mathrm{NO}_{3}-\mathrm{N} \\
\mathrm{mg} / \mathbf{k g} \\
\end{array}$ & $\begin{array}{c}\mathbf{P}_{2} \mathbf{O}_{5} \\
\mathrm{mg} / \mathrm{kg}\end{array}$ & $\begin{array}{c}\mathbf{K}_{2} \mathbf{O} \\
\mathbf{m g} / \mathbf{k g}\end{array}$ & $\underset{\mathrm{mg} / \mathrm{kg}}{\mathbf{M g}}$ & $\underset{\mathrm{mg} / \mathrm{kg}}{\mathrm{Na}}$ & $\mathrm{Zn} \mathrm{mg/kg}$ & Mn mg/kg & $\mathrm{Cu} \mathrm{mg/kg}$ \\
\hline $0-10$ & 1.64 & 2115 & 349 & 198 & 25.1 & 9.08 & 197 & 5.72 \\
\hline 90-100 & 1.13 & 2431 & 170 & 188 & 37.4 & 16.0 & 495 & 8.30 \\
\hline $100-110$ & 1.13 & 2962 & 268 & 188 & 37.6 & 20.9 & 308 & 8.22 \\
\hline $110-120$ & 0.62 & 3635 & 251 & 183 & 40.0 & 20.9 & 107 & 7.56 \\
\hline $120-130$ & 1.64 & 3200 & 227 & 180 & 32.6 & 15.9 & 284 & 6.04 \\
\hline $130-140$ & 16.6 & 2923 & 268 & 195 & 194 & 54.9 & 83.5 & 5.42 \\
\hline $160-170$ & 2.40 & 1295 & 270 & 178 & 24.2 & 6.38 & 473 & 6.06 \\
\hline $200-210$ & 13.8 & 2669 & 294 & 188 & 31.0 & 13.2 & 349 & 6.80 \\
\hline $210-220$ & 13.6 & 2372 & 275 & 185 & 36.1 & 11.7 & 46.9 & 7.24 \\
\hline $230-240$ & 10.0 & 958 & 208 & 178 & 40.0 & 4.10 & 222 & 4.68 \\
\hline
\end{tabular}

low manganese content and thus higher ground-water level (high precipitation) (Nowlan 1976; Solti 2000); two of these events occur during the Gothic settlement period $(120-130$ and $110-120 \mathrm{~cm})$.

\section{Phytolith analysis}

For the presentation of the results we used the term "Phytolith Zone", but the separation of these zones is based on the macroscopic characteristics of the section and not on their phytolith content. Since we could not take samples and analyze phytoliths at the same intervals over the full length of the section, we did not separate the phytolith zones on the basis of the phytoliths themselves. Figure 5 shows a few forms of phytoliths from the samples.

Fig. $5 \rightarrow$

Phytoliths forms from the analyzed samples 


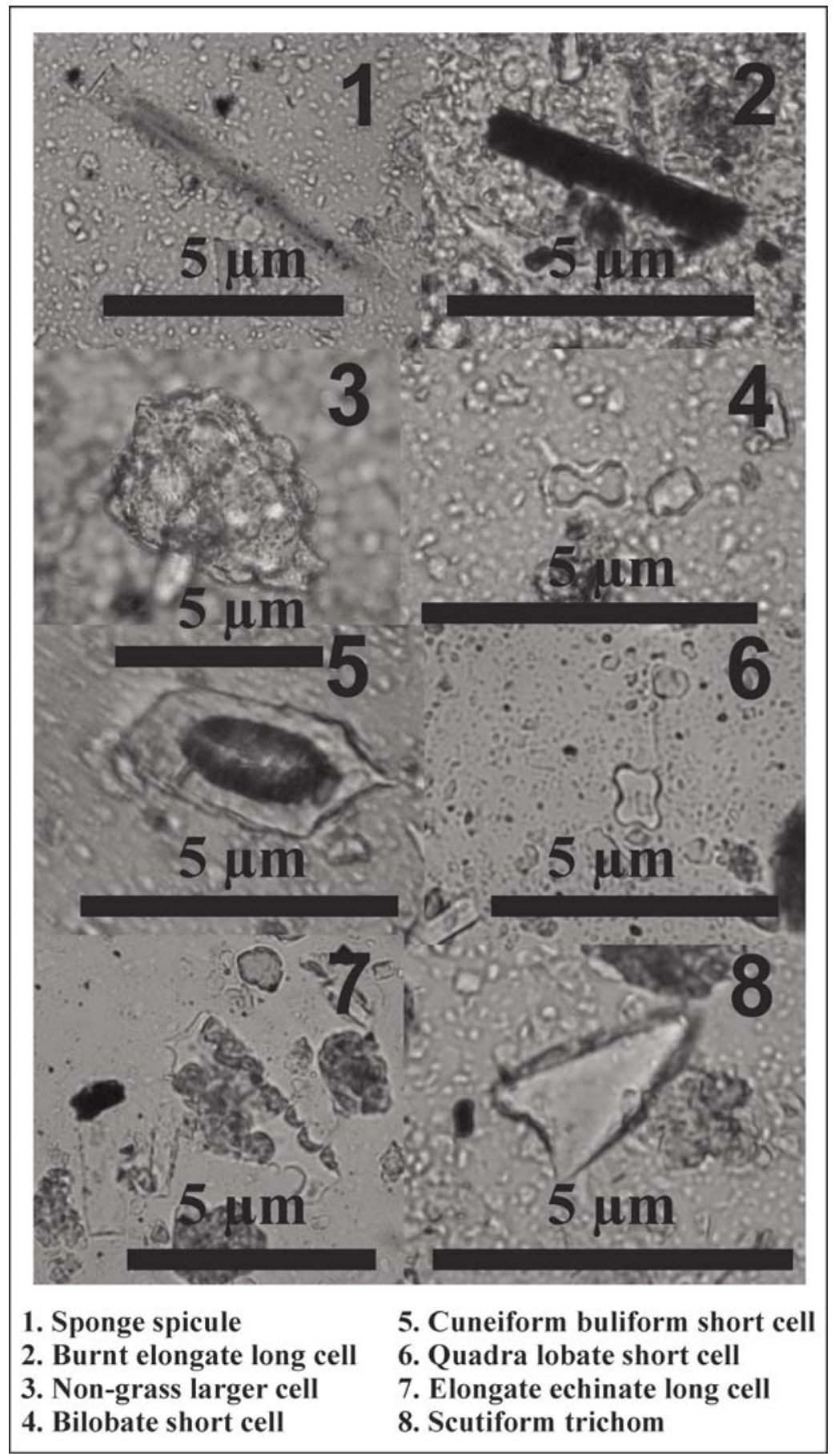

Central European Geology 55, 2012 
Phytolith Zone I, sample GF-10 (230-240 cm)

There were only a few phytoliths in the sample. They were colorless, an indication of forest and forest steppe areas (Golyeva 2001). The small amount of phytoliths suggests erosion; at the same time the phytoliths larger than $20 \mu \mathrm{m}$ are a sign of pioneer vegetation (Golyeva 2001) (Fig. 6). On the basis of the ratio of elongate phytoliths $(<70 \%)$ hydromorphic soils can be reconstructed, which is to be expected at the bank of the Târnava River. The phytolith ratio of trees (nongrass larger cell, NGLC) is 6\%, which points to a significant ratio of woody stems. We must note here that the phytolith production capability of trees is less than that of the herbaceous plants (Golyeva 2001). Thus, the ratio of trees must be higher than can be seen from the ratio of their phytoliths. Mostly elongate phytoliths, within the E. echinate type, were found.

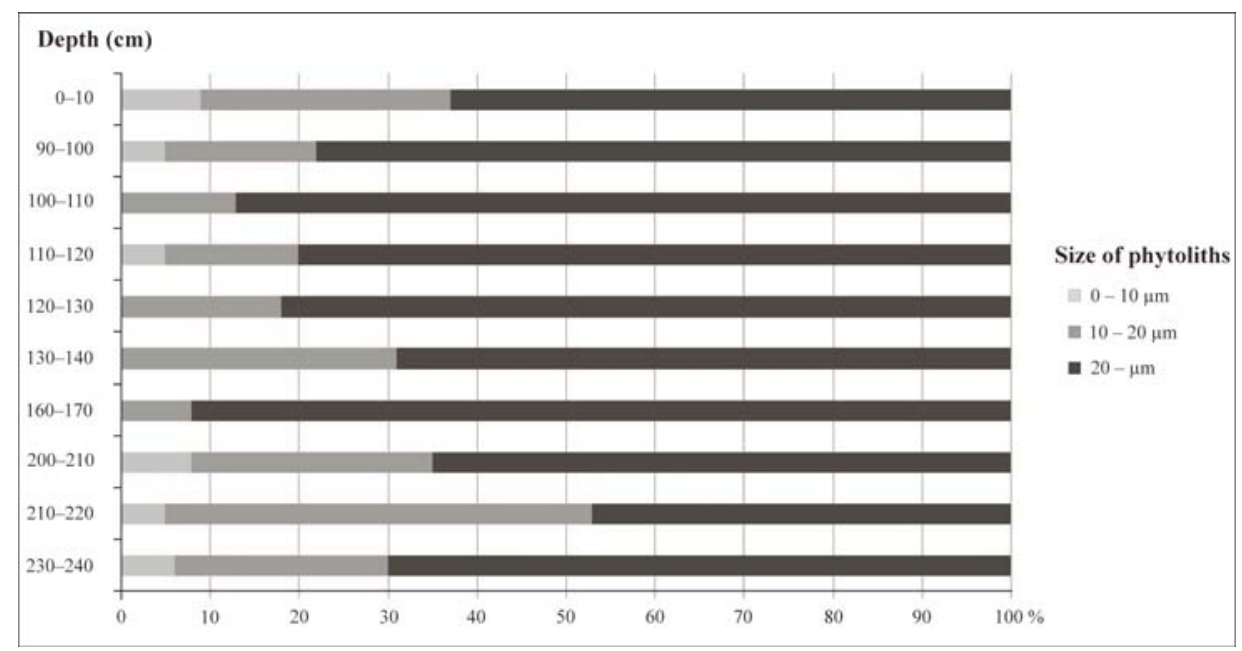

Fig. 6

Size distribution of the analyzed phytoliths

Beside elongate ones, only bilobate, rectangular and scutiform (Fig. 7) phytoliths were found, so the morphological diversity of the sample is poor. Elongate phytoliths indicate the most widespread, general form among Poaceae. The rectangular form (10\%) indicates a cold and wet climate (festucoid form), while bilobate (5\%) phytoliths point to a wet and mild climate (panacoid form). The scutiform type is derived from the trichome of Poaceae species of the forest habitat (Golyeva 2001). On the basis of these results we can reconstruct an open forest where the presence of trees is still significant, but the ratio of open areas is in preponderance. On hydromorphic soils diverse herbaceous vegetation develop where species that favor mild climate appear as well. 


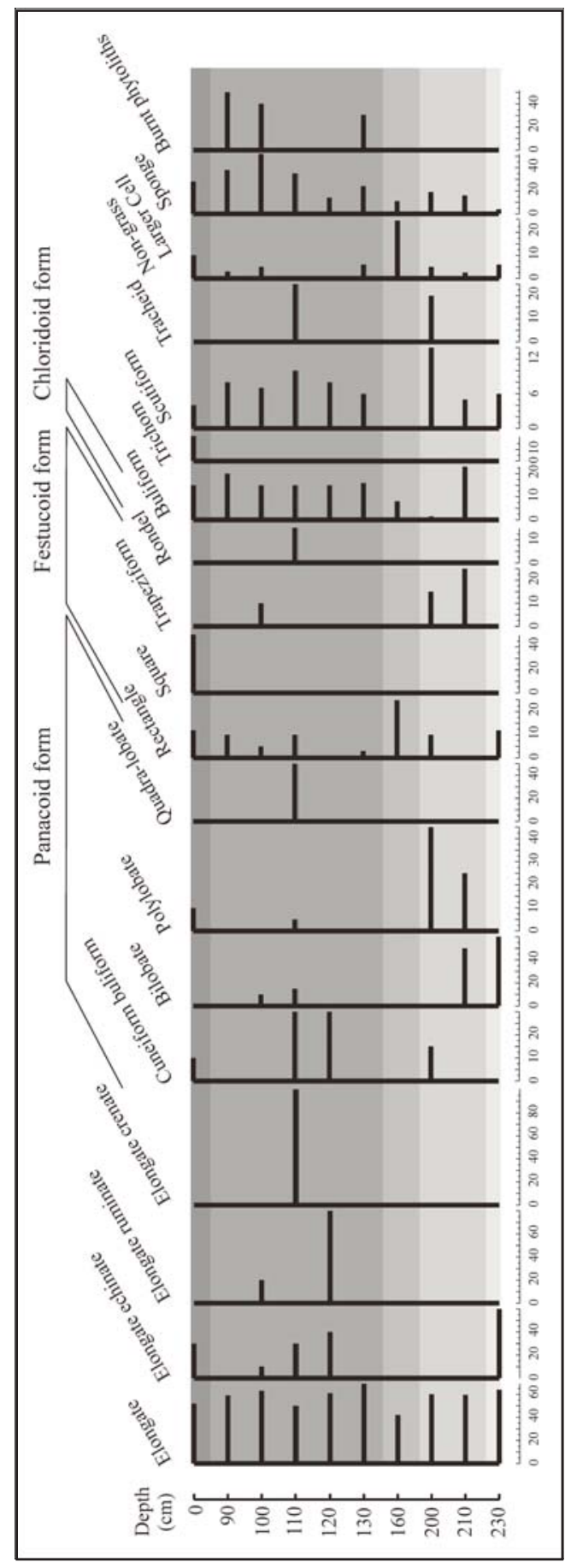

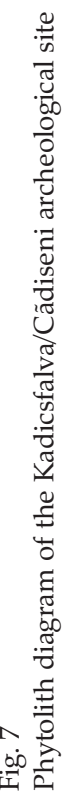

Central European Geology 55, 2012 
Phytolith Zone II, sample GF-9 (220-210 cm) and sample GF-8 (210-200 cm)

The phytoliths are still colorless but their size dominance varies. Between 210 and $220 \mathrm{~cm}$ the ratio of average and large phytoliths is similar; however, between 200 and $210 \mathrm{~cm}$ the ratio of phytoliths larger than $20 \mu \mathrm{m}$ is again the highest. The amount of phytoliths is still low. Elongate ones dominated (59.5\%), indicating hydromorphic soil.

Decorated long phytoliths disappear from the zone; at the same time eight different herbaceous phytolith forms appear. Most of these indicate a cold and wet or warm and wet climate. The ratio of dumbbell-shaped forms (bilobate and polylobate phytoliths) is typical for this zone, pointing to a typical meadow habitat (Golyeva 2001). At the beginning of the zone the ratio of phytoliths of trees (NGLC) is attenuated; however, at the end of this zone it reached the same ratio as in Phytolith Zone I again. At this level the ratio of scutiform phytoliths, belonging to Poaceae, doubled compared to the previous zone, an indication of forest habitat. The ratio of tree phytoliths increased at the end of the zone but this change is not significant. Taking into account that the number of phytoliths is very low, probably the ratio of trees became stable or it decreased. The explanation for this is that the diversity of herbaceous phytoliths changed abruptly and the ratio of thermophilous forms (species) increased. Since phytoliths forms of meadow and forest grasses increased as well, the opening up of the forest consolidated was probably in this zone.

Phytolith Zone III, sample GF-7 (160-170 cm)

This zone contained only a small amount of phytoliths. The most important reason for this is most probably deforestation: there are less phytoliths in soils of forests than in open areas, which are covered by herbaceous plants (Golyeva 2001). Deforestation is supported by the ratio of trees and shrub (25\%) that is the highest in the section. The diversity of phytoliths is minimal. Besides elongate forms only rectangular phytoliths $(25 \%)$ were found, an indication of a cold and wet climate (Golyeva 2001). In addition, buliform phytoliths appear that, based on their size, also point to a forest habitat. It is worth noting that Poaceae phytoliths typical for a forest habitat (scutiform) are absent, possibly indicating an intensive forest inclusion.

Phytolith Zone IV, samples GF-6, GF-5, GF-4, GF-3, GF-2 (140-90 cm, at 10-cm intervals)

This zone is of special importance since the most dynamic human impact occurred at this level. The sampling of the paleosoil at the archeological site was undertaken at $10-\mathrm{cm}$ intervals. The amount of phytoliths is the highest in this zone. On the basis of the secondary characteristics of the phytoliths (color, dominant size, size and ratio of elongate phytoliths) the development of hydromorphic soil can be reconstructed. A noteworthy characteristic is that 
parallel to the increase in the number of phytoliths, the ratio of sponge spicules is the highest in this zone as well. This is typical of flood plains, alluvial fans and the vicinity of river channels (Golyeva 2001). There is a transition phase at the bottom of the zone where the number of tree phytoliths (NGLC) decrease; after this they disappear. So the area opens up, presumably due to anthropogenic impact. The phytoliths of trees only appear again at the end of the zone.

Throughout the zone elongate phytoliths predominated, but at the beginning and at the end of the zone (GF-6 and GF-2) their ratio was partly attenuated. Burned phytoliths appear in these zones as well that are elongate, namely Poaceae phytoliths, so most probably they reflect burning in an open area and not forest burning.

In the middle part of the zone (GF-5, GF-4, GF-3) the formal diversity of phytoliths increased, especially those that favor a mild and wet climate. However, their ratio is still lower than the ratio of phytolith forms that indicate a cold and wet climate. At the same time, in this middle zone elongate echinates appear, which are very frequent in cereals; a more exact identification is not possible. Probably they originated from cereal waste (chaff, or other parts of plants outside the seed). Reed (Phargmites australis) phytoliths (cuneiform buliform) appeared in the middle part of the zone as well; they may have been derived from the roof system of the former buildings. Forest habitat-type Poaceae phytoliths (scutiform) are present and close to these buliform phytoliths, indicating that during the human presence in this period a high degree of forest cover was characteristic near the settlement. However, there was no forest cover in the settlement itself because the ratio of phytoliths of trees (NGLC) and scutiform types does not support this.

We must note that phytoliths typical for the steppe (rondel) occurred only in one sample, namely in the middle part of the zone (GF-4). This may indicate the most intensive anthropogenic effect. Burned phytoliths appear again at the end of the zone; phytoliths of trees increase and the diversity of herbaceous phytoliths decreases. It is interesting that in this zone and in the previous Zone III, meadow phytolith forms (bilobate, polylobate) that are present at the beginning and at the end of the section, are absent. Based on these results the environment of the culture layer differs from the reforested (Zone II) and from the open gallery forest stage.

\section{Phytolith Zone V, sample GF-1 $(0-10 \mathrm{~cm})$}

Although we analyzed the zone for phytoliths, due to the disturbed nature of the area the result of the analysis must be interpreted with care. The trend is similar to Phytolith Zone V, but due to the archeological excavations and the waste dumping after that, we do not know the extent of the hiatus in the section; it is doubtful that the samples derive from the recent soil horizon. 


\section{Palynological analysis}

It was possible to detect 63 taxa ( 22 woody, 32 herbaceous typical for dry-land and 9 aquatic, waterside and sporiferous) in the pollen material.

On the basis of Cluster Analysis and PCA bi-plot diagram (Figs 8 and 9) it was not possible to distinguish between samples derived from the end of the Pleistocene and early Holocene. Therefore a continuous vegetation change could be reconstructed from the cold steppe mixed with taiga and tundra, through the mixed taiga to the Early Holocene deciduous forest. At the same time, two additional factors could explain why samples from the late Pleistocene and early Holocene could not be significantly separated from each other.

One of the factors is the prehistoric population that settled on the old Holocene soil. Due to human effect the soil and its bedrock (the alluvial loess) were mixed; furthermore, bioturbation could cause the mixture of the two levels during soil formation as well. The study area is also important since due to the basin location, the accumulation of pollen grains derived from higher altitudes (pine belt) is significant. This can be detected in the significant ratio of pollen grains during the Holocene and in the recent samples of the section (Figs 10 and 11).

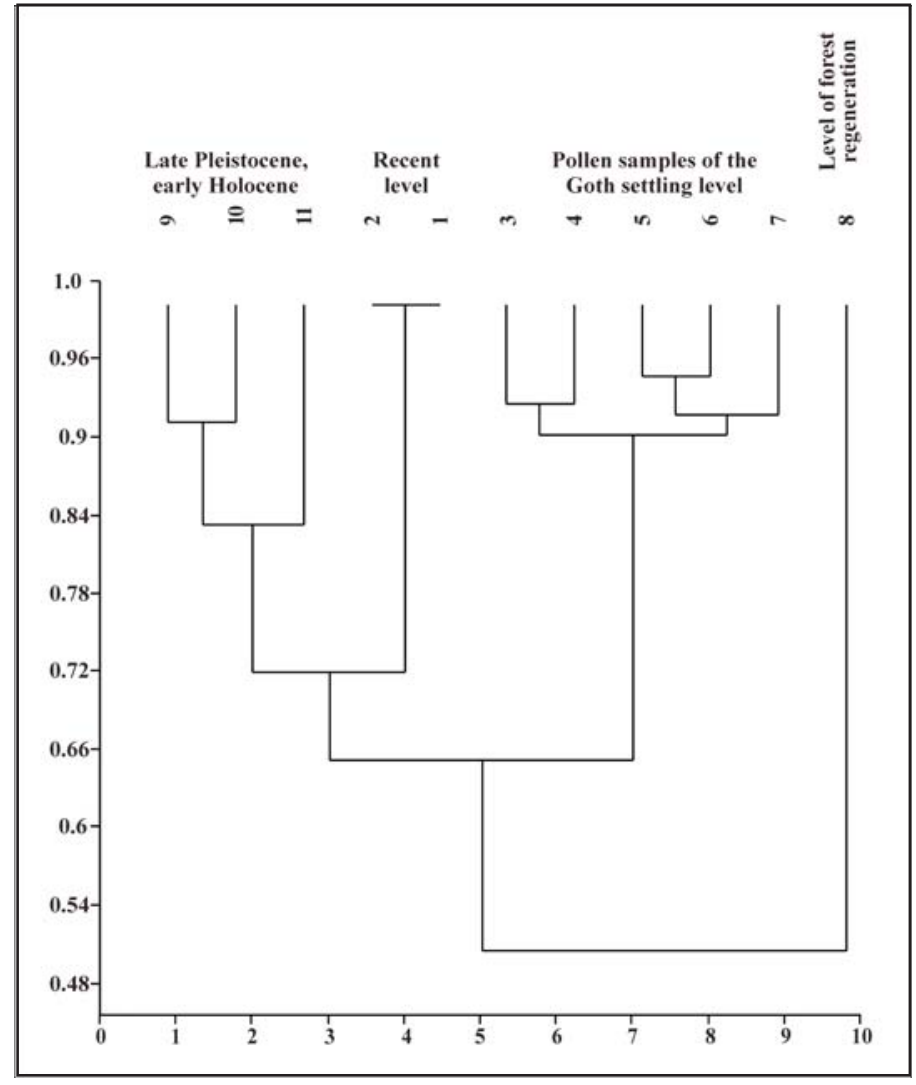

Fig. 8

Cluster diagram of pollen samples of the Kadicsfalva Cãdiseni archeological site 


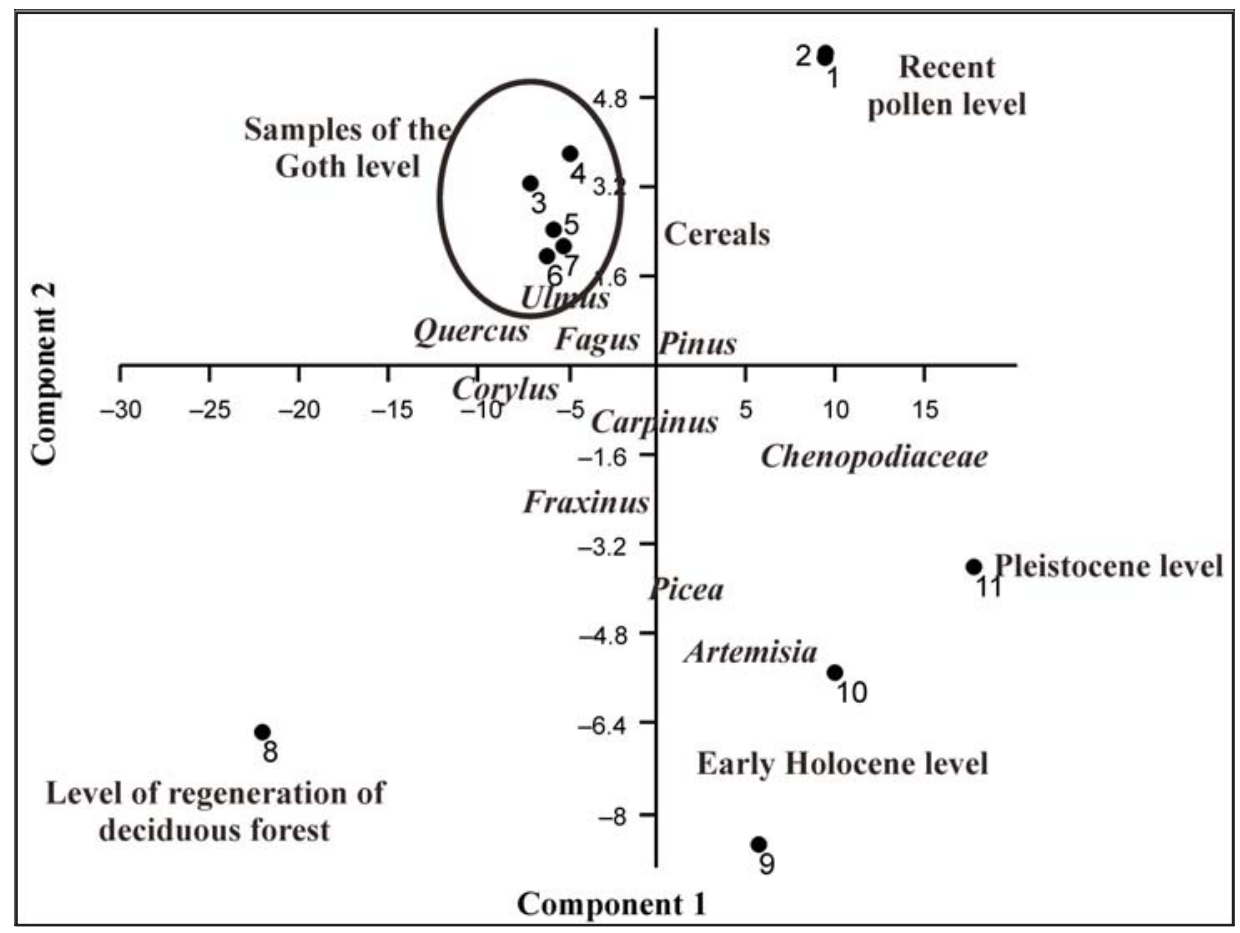

Fig. 9

PCA bi-plot diagram of pollen samples of the Kadicsfalva/Cãdiseni archeological site

The pollen material of the Gothic settlement level is monotonous and a specific environmental utilization can be outlined. The earlier developed deciduous forest was burned (Fig. 10, Fraxinus maximum); probably pastures, roads and settlement levels were created and grain fields were established on the basis of palynological analysis and archeological evidence (Körösfői et al. 2009, 2010). Interestingly, among the cereals ancient grain types were preserved because grain pollens larger than $60 \mu \mathrm{m}$ were detected at this level. Beside wheat, oat and rye could be identified. On the basis of these finds, extensive cereal production was a characteristic of the settled Goth population.

Weeds of cereals and pastures, toxic and stinging herbs (Fig. 11) (thistle Cirsium, plantain - Plantago, docks - Rumex, bedstraw - Galium, euphorbia Euphorbia, centaurea - Centaurea) indicate plant cultivation, pasture lands and trampled areas in the vicinity of the settlements. Beside weeds that occur in a significant amount the ratio of Poaceae is high, as well as the ratio of entomophilous flowers, so an open area can be reconstructed in the area surrounding the Gothic settlement. The pediments may have been forested because Ulmus, Quercus, Fagus and Carpinus pollen were found, but at higher altitudes Pinus sylvestris and Picea dominated. Alnus, Betula and Salix covered the 


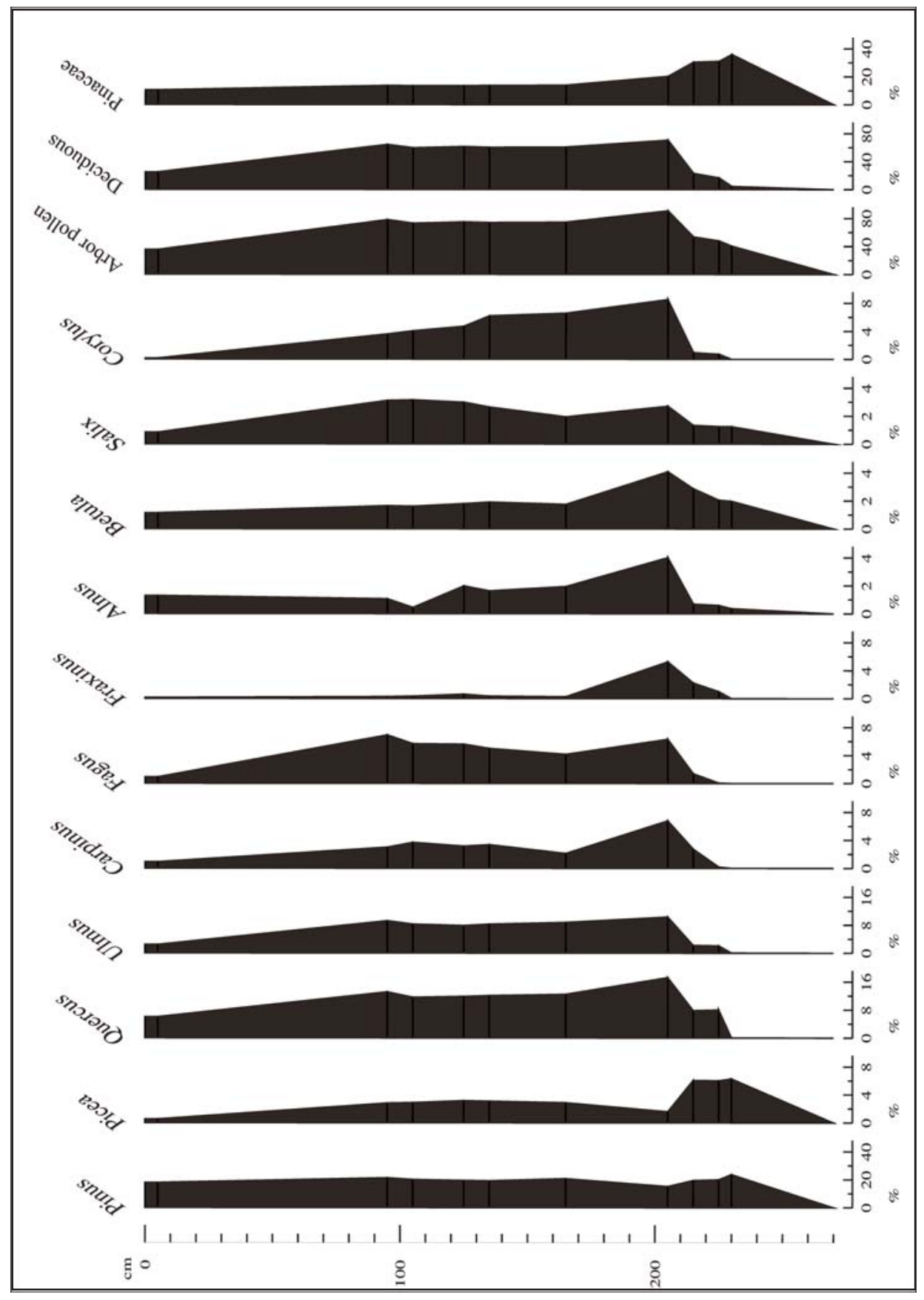

Central European Geology 55, 2012 
riversides. Forest were disturbed and under strong human impact, reflected in the significant ratio of Corylus and Sambucus (Fig. 10). These sunshine-loving shrubs spread along roads, forest edges and over cleared areas due to human disturbance, so an intense anthropogenic effect can be reconstructed.

\section{Malacological analysis}

Ten samples underwent flotation and were selected for identification of mollusk remains. Unfortunately only two levels, the Pleistocene loess horizon and the Gothic settlement level, contained identifiable mollusk shells, mainly fossils of gastropods.

From the loess material $(230-240 \mathrm{~cm})$ a fragment of Valvata pulchella, a coldtolerant aquatic snail that was widespread in NE Europe, was found, as well as a small shell fragment that belong to the Trichia genus but is unidentifiable at species level. Both taxa indicate a cold, wet, water or waterside environment and this supports the results of phytolith and pollen analysis, namely that the loess material accumulated in a cold steppe area where tundra and pine patches were mixed in a waterside environment.

From the Gothic level a few fragments of Vallonia shell occurred. Vallonia pulchella and Vallonia costata were certainly present in the sediment on the basis of stoma fragments, but other Vallonia species could not be identified due to the small size of the fragments. Besides Vallonia a small epiphragma that belongs to Limacidae was found.

Both of the Vallonia species and the Limacidae taxa occur in ruderal plant associations, forest edges, in areas covered with high weeds, and can be found in human settlements as well especially in gardens and in the proximity of manure. Their presence supports the results of phytolith and pollen analyses; a human settlement composed of patches of cultivated lands, gardens, roads and forests can be reconstructed during the time of Gothic settlement.

\section{Conclusions}

On the basis of the lithologic, sedimentological, palynological, phytolith and malacological analyses, the following environmental historical events can be reconstructed for the study area. Figure 12 summarizes the results.

1. At the end of the Pleistocene a significant amount of gravel sand and sandy gravel was accumulated by the Târnava River and on the basis of geomorphologic analysis and 3D models (Figs 13 and 14) the fluvial sediments accumulated directly in front of the pediment. The Pleistocene gravel deposit is in a raised

$\leftarrow$ Fig. 10

Arboreal pollen diagram of the Kadicsfalva/Cãdiseni archeological site 


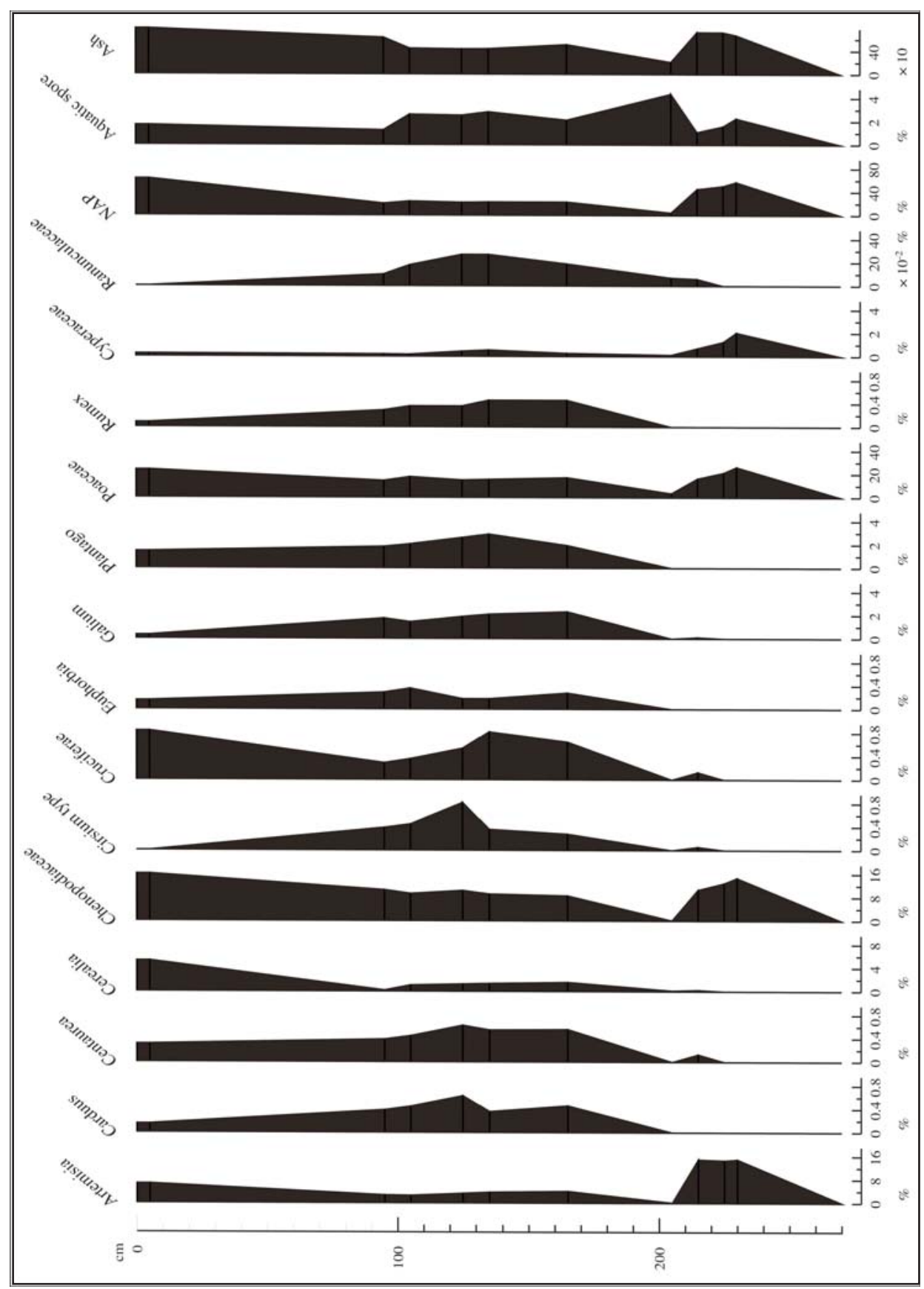




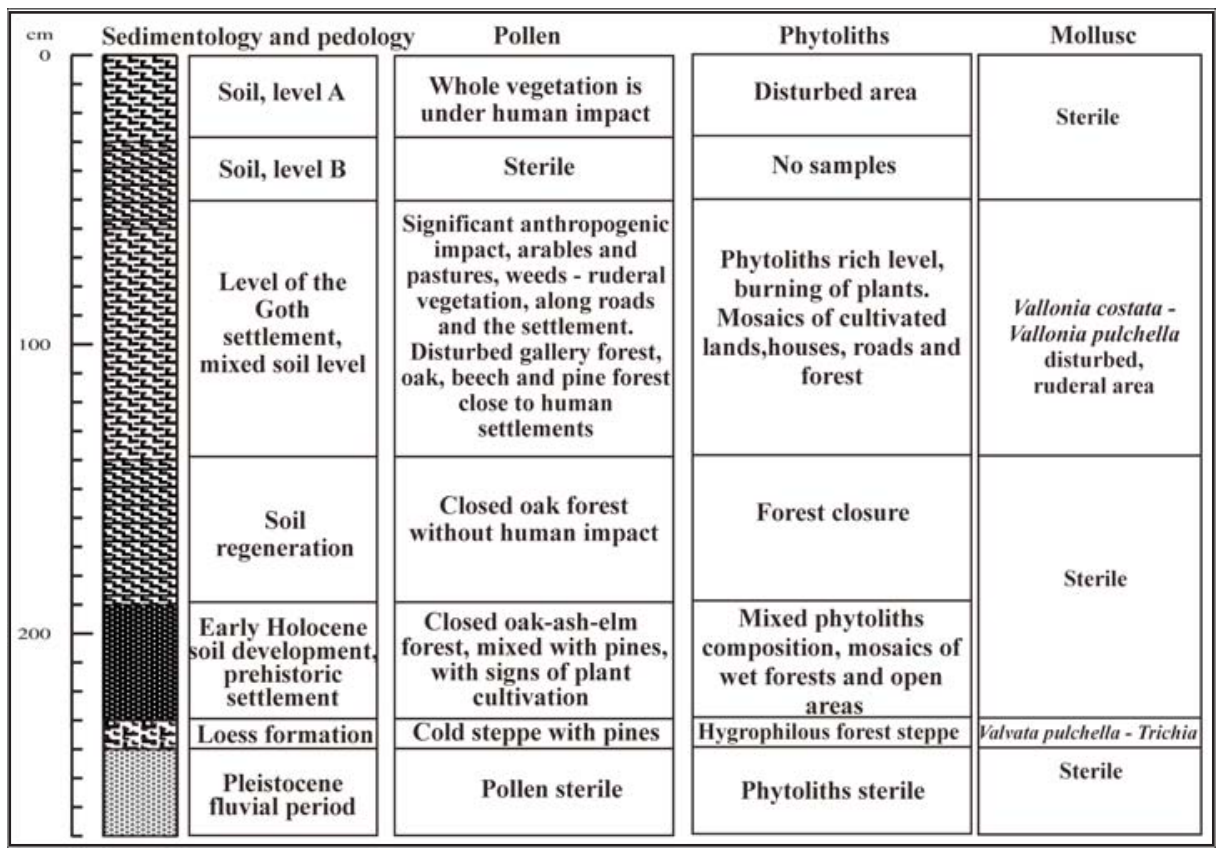

Fig. 12

Comprehensive results of the section of the Kadicsfalva/Cãdiseni archeological site

position compared to the Holocene valley and forms an elongated terrace-like formation between the deeper alluvium and the pediment.

2. Afterward loess and alluvial loess developed from the eolian dust that accumulated on the wet surfaces of the Pleistocene sediments. At the end of the Pleistocene the Târnava River incised into its own deposit and loess diagenesis took place on the gradually parched surface. In the contour map (Fig. 13) of Kadicsfalva/Cãdiseni the 50-100 m-wide zone of the terrace horizon (light grey on the map) can be clearly identified and can be characterized by minimal surface roughness.

In the 3D model (Fig. 14) the terrace surface seems to be almost horizontal, an ideal surface for settlement since it was near water and ideal for cultivating land. The advantage of the area is that it lies between the gallery forest of the river bank and the pediment covered by oak forest, so the woody material important as construction timber and fuel was available within a short distance. Thus the area had favorable conditions for the establishment of a settlement and for long-term colonization.

$\leftarrow$ Fig. 11

Non-arboreal pollen diagram of the Kadicsfalva/Cãdiseni archeological site 


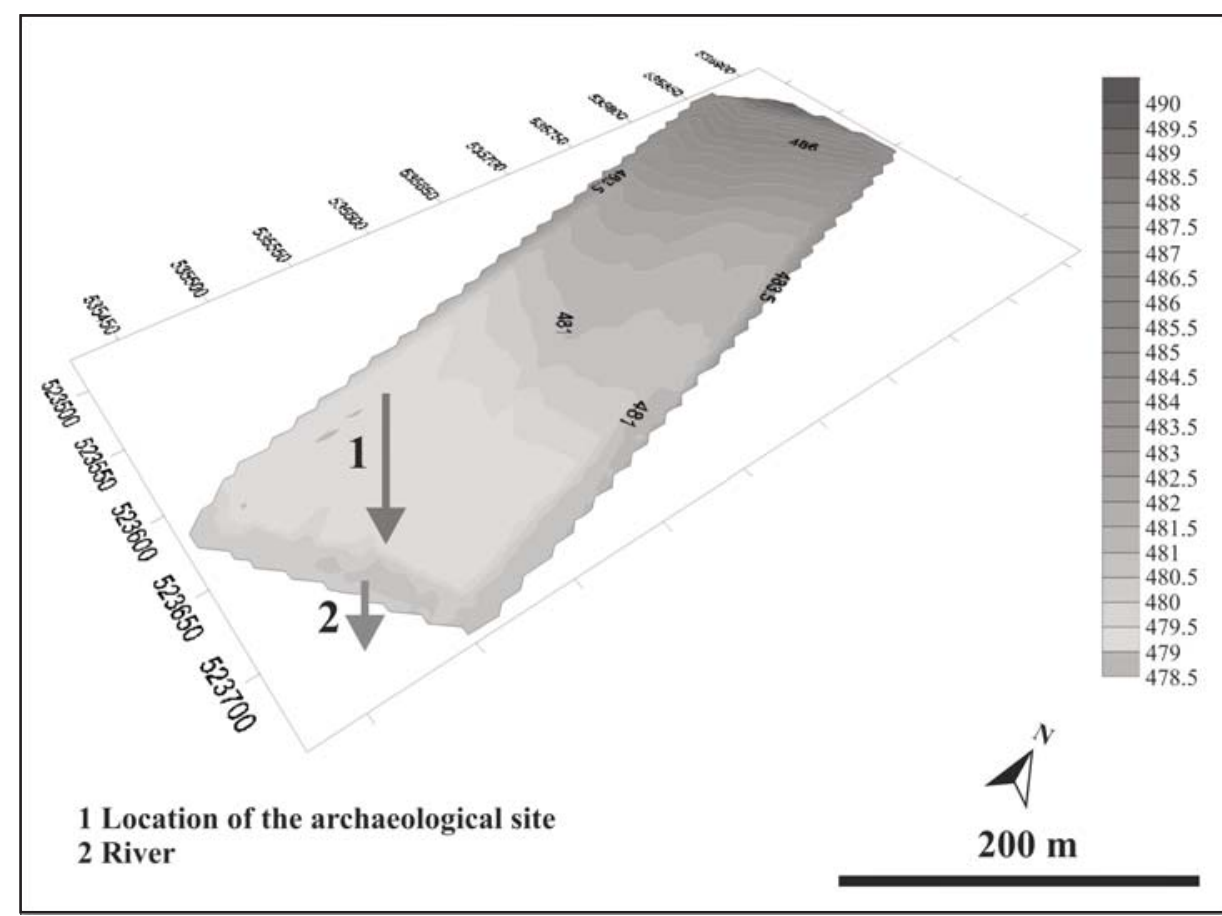

Fig. 13

Contour map of the Kadicsfalva/Cãdiseni archeological site

At the same time, from the direction of the slope, redeposited sediments and soil accumulated on the terrace. Thus, it is difficult to recognize the layered structure of the excavated, extremely thick (more than $2 \mathrm{~m}$ ) soil sequence.

3. In spite of the fact that the loess-covered terrace had several advantages for settlement, other problems were linked to this surface. On the one hand, only a long but narrow strip of land was available for colonization. On the other hand, the floods of Târnava River and the rainwater coming from the pediment caused significant problems. The reason for the latter is forest destruction and burning that caused soil and mud flow (Alexander 1992; Zheng et al. 2005). On the basis of palynological, phytolith and malacological evidence the Gothic populations protected themselves architecturally by building houses on stilts or by establishing settlements with gardens, forest patches, arable and pasture lands between houses or roads. These results support previous ones (Bóna 1986), namely that the oak, beech and pine-dominated forest was close to the human se

4. Another major problem is the linearity of the settlement; namely the settlement and the cultivated lands could only be established on the loesscovered terrace surfaces. Any lateral shift towards the pediment would result in farming degraded soil; toward the river bank the danger of inundation was the 


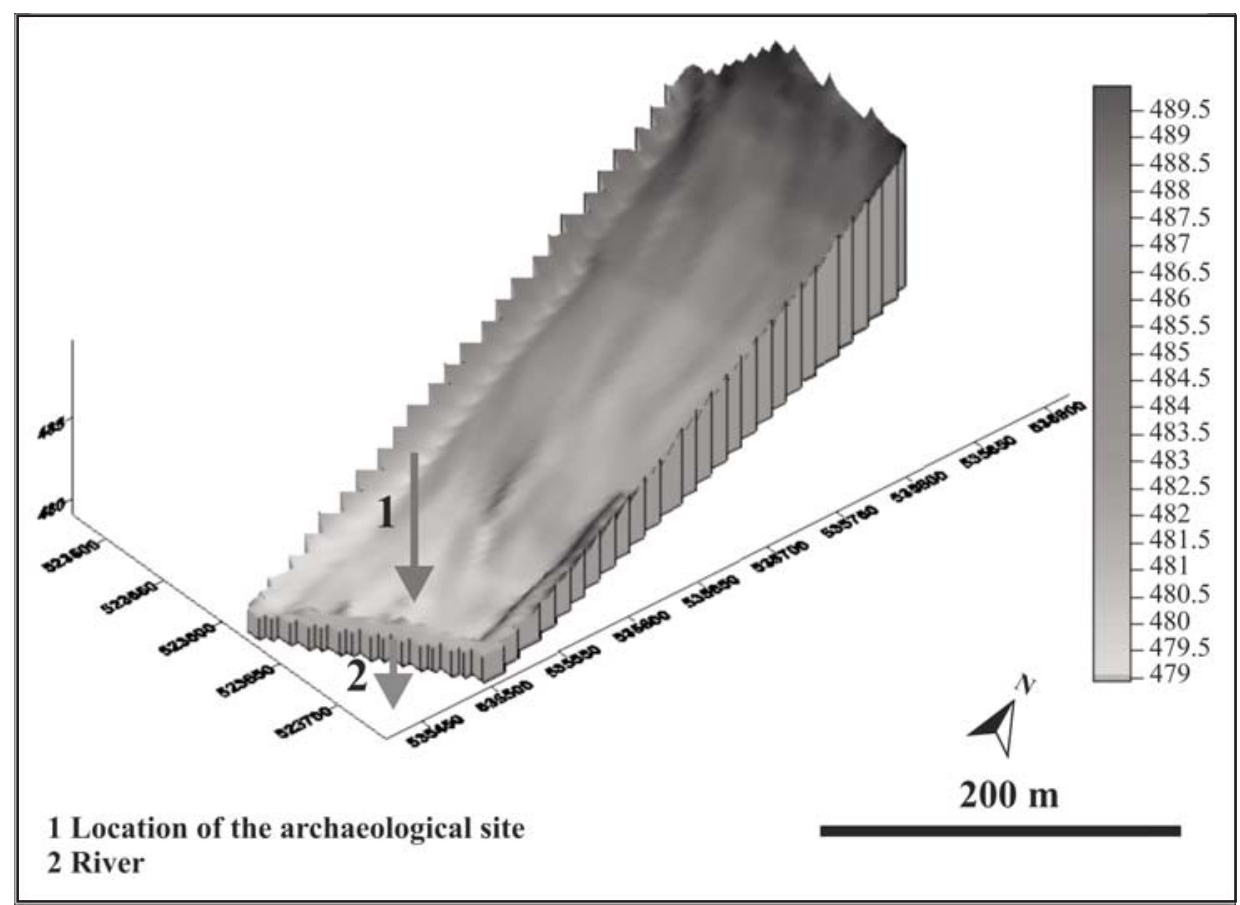

Fig. 14

Digital relief map of the Kadicsfalva/Cãdiseni archeological site

limiting factor. So in the case of population growth later generations were faced with new problems; defense of the settlement became more difficult due to its elongated shape. Thus, after reaching a certain length, the settlement probably broke into several parts.

The comparative analysis of our samples indicates that compared to the Gothic settlement period, the recent soil horizon is over-utilized; its productivity can be maintained only by intensive fertilization and almost every one of its parameters is below the element and nutrient composition of the Gothic soil horizon.

\section{Acknowledgements}

We would like to express our gratitude to Dr. Dávid Gergely Páll and to Zsolt Veres for their help during the sampling process. This study was carried out through the scholarship TÁMOP-4.2.1/B-09/1/KONV-2010-0005 and TÁMOP4.2.2/B-10/1-2010-0012. 


\section{References}

Alexander, D. 1992: On the causes of landslides: Human activities, perception, and natural processes. - Environmental Geology and Water Sciences, 3, pp. 165-179.

Ant, H. 1963: Faunistische, ökologische und tiergeographische Untersuchungen zur Verbreitung der Landschaften in Nordwestdeutschland. - Abh. Landesmus, Naturkunde Münster 25, pp. 1-25.

Bába, K. 1983a: Magyarország szárazföldi csigáinak állatföldrajzi besorolásához felhasznált faj-area térképek (Species-area maps of Hungarian terrestrial snails for their zoogeographical arrangement). - Folia Musei Historico-naturalis Musei Matraensis, 8, pp. 129-132.

Bába, K. 1983b: A Szatmár-Beregi sík szárazföldi csigái és a környezetükre levonható következtetések (Terrestrial snails of the Szatmár-Bereg Plain and the conclusion about the environment). - Acta Academiae Paedagogienis, Szeged, Series Biologica-Geographica, 12, pp. 27-41.

Bába, K. 1986: Magyarország szárazföldi csigáinak állatföldrajzi besorolásához felhasznált faj-area térképek II (Species-area maps of Hungarian terrestrial snails for their zoogeographical arrangement II). - Folia Musei Historico-naturalis Musei Matraensis, 11, pp. 49-69.

Báldi, T. 1980: The early history of Paratethys. - Földtani Közlöny, 110, pp. 456-472.

Bengtsson, L., M. Enell 1986: Chemical analysis. - In: Berglund, B.E. (Ed.): Handbook of Holocene Palaeoecology and Palaeohydrology. John Wiley and Sons Ldt., Chichester, pp. 423-451.

Benkő, E. 1992: A középkori Keresztúr-szék régészeti topográfiája (Archaeological topography of the medieval Keresztúr-szék). - Varia Archaeologica Hungarica, 5, pp. 181-183.

Benkő, E. 2012: A középkori Székelyföld. I-II (The medieval Székely Land I-II). - MTA Régészeti Intézet Kiadványa, Budapest.

Bennett, K. 1992: PSIMPOLL - A quickBasic program that generates PostScript page description of pollen diagrams. - INQUA Commission for the study of the Holocene: working group on data handling methods, Newsletter 8, pp. 11-12.

Bennett, K., K.J. Willis 2001: Pollen. - In: Smol J., J. Birks, W.M. Last (Eds): Tracking Environmental Change Using Lake Sediments, Volume 3: Terrestrial, Algal, and Siliceous Indicators. Dordrecht, The Netherlands, Kluwer Academic Publishers, pp. 5-30

Bennett, K. 2005: PSIMPOLL 4.25 and PSCOMB 1.03: C programs for plotting pollen diagrams and analysing pollen data. - Uppsala University, Uppsala, Sweden.

Beug, H.J. 2004: Leitfaden der Pollenbestimmung für Mitteleuropa und angrenzende Gebiete. München, Pfeil-Verlag, $542 \mathrm{p}$.

Birks, H.J.B., H. Birks 1980: Quaternary Palaeoecology. - Edward Arnold Press, London, 289 p.

Birks, H.J.B., A.D. Gordon 1985: Numerical methods in Quaternary pollen analysis. - Academic Press, London, 317 p.

Boycott, A.E. 1934: The habitats of land Mollusca in Britain. - Journal of Animal Ecology 22, pp. 1-38.

Bóna, I. 1986: Erdei emberek: A gótok Erdélyben. (Forest people: the Goths in Transylvania). - In: Köpeczi, B. fószerk. Erdély története I. (The history of Transylvania) Akadémiai Kiadó, Budapest, pp. 1-139.

Braun, M., P. Sümegi, A. Tóth, K.J. Willis, I. Szalóki, Z. Margitai, A. Somogyi 2005: Reconstruction of long-term environmental changes at Kelemér, in Hungary. - In: Gál, E., I. Juhász, P. Sümegi (Eds): Environmental Archaeology in North-Eastern Hungary. Varia Archaeologica Hungarica, 19, Archaeological Institute, Budapest, pp. 25-38.

Casagrande, A. 1934: Die Aräometer-Methode zur Bestimmung der Kornverteilung von Böden und anderer Materialien. - Springer, Berlin, $56 \mathrm{p}$.

Casagrande, A. 1947: Classification and Identification of Soils. - Proceeding of American Society of Civic Engineers, 78, pp. 783-810.

Ciolkosz, E.J., W.J. Waltman, T.W. Simpson, R.R. Dobos 1989: Distribution and genesis of soils of the northeastern United States. - Geomorphology, 2, pp. 285-302.

Csontos, L. 1995: Tertiary evolution of the Intracarpathian area: a review. - Acta Vulcanologica, 7, pp. $1-15$. 
Dániel, P. 2004: Geochemical analysis. - In: Sümegi, P., S. Gulyás (Eds): The Geohistory of Bátorliget Marshland. Archaeolingua Press, Budapest, pp. 52-57.

Dean, W.E. 1974: Determination of the carbonate and organic matter in calcareous sediments and sedimentary rocks by loss on ignitions: comparison with order methods. - Journal of Sedimentary Petrology, 44, pp. 242-248.

Ehrmann, P. 1933: Weichtiere, Mollusca. Tierwelt Mitteleuropas II. - Quelle-Meyer, Leipzig, 264 p. Evans, J.G. 1972: Land Snails in Archeology. - Seminar Press, London, 436 p.

Fodor, F. 1936: The geography of Transylvania. - Jancsó Benedek Társaság kiadványa, Budapest.

Gál, L. 2004: Bányapatak völgyének fitocönológiai és florisztikai bemutatása (Phytocenological and floristical presentation of Bányapatak valley). - A Csíki Székely Múzeum Évkönyve, 1, pp. 379-399.

Golyeva, A. 2001: Biomorphic analysis as a part of soil morphological investigations. - Catena, 43, pp. 217-230.

Greguss, P. 1945: A középeurópai lomblevelú fák és cserjék meghatározása szövettani alapon (Anatomical identification of Central European trees and shrubs). - Országos Magyar Természettudományi Múzeum, Budapest, 159 p.

Greguss, P. 1972: Xylotomy of the living conifers. - Akadémiai Kiadó, Budapest, 329 p.

Gyulai, F. 2001: Archeobotanika. A kultúrnövények története a Kárpát-medencében a régészeti növénytani vizsgálatok alapján (Archaeobotany. History of cultivated plants in the Carpathian Basin on the basis of archaeological-botanical analysis). - Jószöveg Kézikönyvek Kiadó, Debrecen. $240 \mathrm{p}$.

IUSS Working Group WRB 2007: World Reference Base for Soil Resources 2006, first update 2007. World Soil Resources Reports No. 103, FAO, Rome, 116 p.

Jacomet, S., A. Kreuz 1999: Archäobotanik. Aufgaben, Methoden und Ergebnisse vegetations- und agrargeschichtlicher Forschung. - Ulmer, Stuttgart, 368 p.

Kerney, M.P., R.A.D. Cameron, J.H. Jungbluth 1983: Die Landschnecken Nord- und Mitteleuropas. Verlag Paul Parey, Hamburg-Berlin, 384 p.

Kézdi, Á. 1970: Talajmechanika I-II .(Soil mechanics I-II) - Tankönyvkiadó, Budapest, 1014 p.

Kiss, M. 2004: Iordanes Getica. A gótok eredete és tettei (Origin and deeds of the Goth). L'Harmattan Kiadó, Budapest, 271 p.

Klemm, W. 1974: Die Verbeitung der rezenten Land-Gehäuse-Schnecken in Österreich. Denkschriften der Österreichischen Akademie der Wissenschaften MathematischNaturwissenschaftliche Klasse, 117, 513 p.

Koopmans, G.F., M.E. Van Der Zeeuw, P.F.A.M. Römkers, W.J. Chardon, O. Oenema 2001: Identification and characterization of phosphorus-rich sandy soils. - Wageningen Journal of Life Sciences, 49, pp. 36-384.

Körösfői, Zs. 2008: A Marosszentanna-Cernjachov-kultúra három temetkezése a Rugonfalvareformátus papilak lelóhelyen (Three burial of the Marosszentanna-Cernjachov culture in Rugonfalva-lutheran site). - Acta Siculica, 2, pp. 189-207.

Körösfő̈i, Zs., Zs. Nyárádi, A. Sófalvi 2009: A Marosszentanna-Csernyahov-kultúra települése Székelyudvarhely-Alsólokon (Settlement of the Marosszentanna-Csernyahov culture in Székelyudvarhely-Alsólok). - Örökségünk folyóirat. Hagyományőrző Forrásközpont 3, 1. Székelyudvarhely.

Körösfói, Zs., Zs. Nyárádi, A. Sófalvi 2010: Bronzkori népek és vizigótok Székelyudvarhely határában (Bronze Age populations and Visigoths in the border of Székelyudvarhely). - Kiállítás- és szakkatalógus. Székelyudvarhely.

Kovács, I. 1912: A marosszentannai népvándorláskori temető (Cemetery of the migration period in Marosszentanna). - Dolgozatok az Erdélyi Nemzeti Múzeum Érem- és Régiségtárából, 3, pp. 251-342.

Krolopp, E. 1983: A magyarországi pleisztocén képződmények malakológiai tagolása (Malacological dissection of Hungarian Pleistocene formations). - Candidate dissertation, Budapest, $160 \mathrm{p}$ 
Levant, M., R. Anthore, J.P. Dupont, B. Hallégout, D. Robbe 1987: Intercomparaison de methodes microgranulometriques appliques a des loess. - In: Pécsi, M., H.M. French (Eds): Loess and Periglacial Phenomena. Akadémiai Kiadó, Budapest, pp. 11-27.

Liharev, I.M., E.S. Rammelmeier 1962: Nazémnimi molluskami na CCCP. - Akadémia Nauka CCCP, Moscow, $574 \mathrm{p}$.

Ložek, V. 1964: Quartärmollusken der Tschechoslowakei. - Rozpravy Ústredniho ústavu geologického, 31, Praha, 374 p.

Madella, M., A. Powers-Jones, M.K. Jones 1998: A Simple method of extraction of opal Phytoliths from sediments using a non-toxic heavy liquid. - Journal of Archaeological Science, 25, pp. 801-803.

Meijer, T. 1985: The pre-Weichselian nonmarine molluscan fauna from Maastricht-Belvédere (Southern Limburg, the Netherlands). - Mededelingen Rijks Geologische Dienst, 39, pp. 75-103.

Moore, P.D., J.A. Webb 1978: An Illustrated Guide to Pollen Analysis. - Halsted Press, New York, 133 p

Moore, P.D., J.A. Webb, M.E. Collinson 1991: Pollen Analysis. - Blackwell Scientific Publications, Oxford, $216 \mathrm{p}$

Nowlan, H.A. 1976: Concretionary manganese-iron oxides in streams and their usefulness as a sample medium for geochemical prospectin. - Journal of Geochemical Exploration, 6, pp. 193-210.

Orlóci, L. 1967: An agglomerative method for classification of plant communities. - Journal of Ecology, 55, pp. 193-205.

Pécskay, Z., J. Lexa, A. Szakács, K. Balogh, I. Seghedi, V. Konecny, M. Kovács, E. Márton, M. Kaliciak, V. Széky-Fux, T. Póka, P. Gyarmati, O. Edelstein, E. Rosu, B. Zec, 1995: Space and time evolution of the Neogene-Quaternary volcanism in the Carpatho-Pannonian Region. - Acta Vulcanologica, 7, pp. 15-28.

Persaits, G. 2010: A fitolitok szerepe a geoarcheológiai minták értékelésében (The importance of phytoliths in geoarchaeological studies). - Doktori értekezés, SZTE TTIK Földtani és Őslénytani Tanszék, Szeged, $147 \mathrm{p}$.

Piperno, D.R. 1988: Phytolith analysis: An Archaeological and Geological Perspective. - Academic Press, Harcourt Brace Jovanovich, Publishers, San Diego, 268. p.

Piperno, D.R. 2006: Phytoliths. A Comprehensive Guide for Archaeologists and Paleoecologists. Altamira Press, Oxford, 238 p.

Podani, J. 1978: Néhány klasszifikációs és ordinációs eljárás alkalmazása a malakofaunisztikai és cönológiai adatok feldologzásában. I. (The application of some classification and ordination methods in the processing of malacofaunistical and cenalogical data I). - Állattani Közlemények, 65, pp. 103-113.

Podani, J. 1979: Néhány klasszifikációs és ordinációs eljárás alkalmazása a malakofaunisztikai és cönológiai adatok feldologzásában. II. The application of some classification and ordination methods in the processing of malacofaunistical and cenalogical data II). - Állattani Közlemények, 66, pp. 85-97.

Podani, J. 1993: SYN-TAX 5.0: Computer programs for multivariate data analysis in ecology and systematics. - Abstracta Botanica, 17, pp. 289-302.

Pósta, B. 1906: A marosszentannai sírmező (Graveyard in Marosszentanna). - In: Az Erdélyi Múzeum-Egyesület Marosvásárhelyt, 1906. június 4-5. napján tartott első vándorgyúlésének emlékkönyve. Erdélyi Múzeum-Egyesület, Kolozsvár, pp. 102-109.

Pradyot, P. 2002: Handbook of the Inorganic Chemicals. - McGrew-Hill, New York.

Reille, M. 1992: Pollen et spores d'europe et d'Afrique du nord, supplement 1. - Laboratoire de Botanique historique et Palynologie, Marseille, $520 \mathrm{p}$.

Schlegel, P., S. Durosoy, A.W. Jongbloed 2008: Trace elements in the animal production system. Wageningen Academic Publishers, Wageningen.

Schweingruber, F.H. 1990: Mikroskopische Holzanatomie. - Eidgenössiche Forschungsantalt für Wald, Schnee und Landschaft, Birmensdorf, 226 p. 
Solti, G. 2000: Talajjavítás és tápanyag-utánpótlás az ökogazdálkodásban (Soil improvement and fertilization in organic farming). - Mezőgazda Kiadó, Budapest, 208 p.

Soós, L. 1943: A Kárpát-medence Mollusca-faunája (Mollusca fauna in Carpahian Basin). Akadémiai Kiadó, Budapest, 478 p.

Southwood, T.R.E. 1978: Ecological methods with particular reference to the study of insect populations. - Chapmann and Hall, London, $391 \mathrm{p}$.

Sparks, B.W. 1961: The ecological interpretation of Quaternary non-marine Mollusca. - Proceedings of the Linnean Society of London. 172, pp. 71-80.

Sümegi, P. 2003: Régészeti geológia és történeti ökológia alapjai (The basics of geoarchaeology and historical ecology). - JATEPress, Szeged, $223 \mathrm{p}$.

Sümegi, P., K. Náfrádi, T. Törőcsik 2011: The methodology employed. - In: Kvassay, J. (Ed.): The late Urnfield period cemetery from Szombathely-Zanat supplemented by an assessment of prehistoric and medieval settlement features and interdisciplinary analyses. VIA Monographia Minor in Cultural Heritage 2. Hungarian National Museum - National Cultural Heritage Protection Centre, pp. 203-214.

Stockmarr, J. 1971: Tablets with Spores used in Absolute Pollen Analysis. - Pollen et Spores, 13, pp. 615-621.

Szakács, A., Cs. Krézsek, 2007: Volcano-basement interaction in the Eastern Carpathians: Explaining unusual tectonic features in the Eastern Transylvanian Basin, Romania. - Journal of Volcanology and Geothermal Research, 158, pp. 6-20.

Szász, J. 1995: Élettani és társulás-ökológia II (Physiological and association ecology II). - Románia növényföldrajza. Kiegészítő jegyzet, Erdészeti és Faipari Egyetem, Sopron.

Timár, G., T. Telbisz, B. Székely 2003: Ưrtechnológia a digitális domborzati modellezésben: az SRTM adatbázis (Space technology in digital elevation model: The SRTM database). - Geodézia és Kartográfia, 55, pp. 11-15.

Tóthmérész, B. 1993: NuCoSA 1.0: Number Cruncher for Community Studies and other Ecological Applications. - Abstracta Botanica, 7, pp. 283-287.

Troels-Smith, J.A. 1955: Karakterisering af lose jordater. - Danmarks Geologiske Undersogelse, Ser. IV, 10.

Twiss, P.C., E. Suess, R.N. Smith 1969: Morphological classification of grass phytoliths. - Soil Science Society of America, Proceedings 33, pp. 109-115.

Unger, Z., G. Timár 2005: Székelyföld lineamens térképe Landsat-TM úrfelvétel alapján (Lineament map of Székelyföld based on Landsat-TM satellite image). - Földtani Közlöny, 135, pp. 293-304.

Vendel, M. 1959: A kôzethatározás módszertana (Methodology of rock identification). - Akadémiai Kiadó, Budapest.

Veres, D. 2002: A comparative study between loss on ignition and total carbon analysis on minerorgenic sediments. - Studie Universitatis Babes-Bolyai, Geologica, 47/1 pp. 171-182.

Ward, J.H. 1963: Hierarchical grouping to optimize an objective function. - Journal of the American statistical Association, 58, pp. 236-244.

Willis, K.J., P. Sümegi, M. Braun, D.B. Keith, A. Tóth 1998: Prehistoric land degradation in Hungary: who, how and why? - Antiquity, 72, pp. 101-113.

Wolfram, H. 1990: History of the Goths. - University of California Press, 613 p.

Zheng, F., X. He, X. Gao, C. Zhang, K. Tang 2005: Effects of erosion patterns on nutrient loss following deforestation on the Loess Plateau of China. - Agriculture, Ecosystems and Environment, 108, pp. 85-97. 